\title{
Tumor cell death after electrotransfer of plasmid DNA is associated with cytosolic DNA sensor upregulation
}

\author{
Katarina Znidar ${ }^{1}$, Masa Bosnjak², Nina Semenova ${ }^{3}$, Olga Pakhomova ${ }^{3}$ Loree \\ Heller $^{3,4}$ and Maja Cemazar ${ }^{1,2}$ \\ ${ }^{1}$ Faculty of Health Sciences, University of Primorska, Izola, Slovenia \\ ${ }^{2}$ Department od Experimental Oncology, Institute of Oncology Ljubljana, Ljubljana, Slovenia \\ ${ }^{3}$ Frank Reidy Research Center of Bioelectrics, Old Dominion University, Norfolk, Virginia, USA \\ ${ }^{4}$ School of Medical Diagnostic and Translational Sciences, Collage of Health Sciences, Old Dominion University, Norfolk, \\ Virginia, USA \\ Correspondence to: Maja Cemazar, email: mcemazar@onko-i.si \\ Loree Heller, email: Iheller@odu.edu
}

Keywords: plasmid DNA; pattern recognition receptors; mammary adenocarcinoma cells; fibrosarcoma cells; electroporation; Immunology

Received: December 26, $2017 \quad$ Accepted: February 27, $2018 \quad$ Published: April 10, 2018

Copyright: Znidar et al. This is an open-access article distributed under the terms of the Creative Commons Attribution License 3.0 (CC BY 3.0), which permits unrestricted use, distribution, and reproduction in any medium, provided the original author and source are credited.

\section{ABSTRACT}

Cytosolic DNA sensors are a subgroup of pattern recognition receptors (PRRs) and are activated by the abnormal presence of the DNA in the cytosol. Their activation leads to the upregulation of pro-inflammatory cytokines and chemokines and can also induce cell death. The presence of cytosolic DNA sensors and inflammatory cytokines in TS/A murine mammary adenocarcinoma and WEHI 164 fibrosarcoma cells was demonstrated using real time reverse transcription polymerase chain reaction (RTPCR), western blotting and enzyme-linked immunosorbent assay (ELISA). After electrotransfer of plasmid DNA (PDNA) using two pulse protocols, the upregulation of DNA-depended activator of interferon regulatory factor or Z-DNA binding protein 1 (DAI/ZBP1), DEAD (Asp-Glu-Ala-Asp) box polypeptide 60 (DDX60) and interferoninducible protein 204 (p204) mRNAs was observed in both tumor cell lines, but their expression was pulse protocol dependent. A decrease in cell survival was also observed; it was cell type, DNA concentration and pulse protocol dependent. Furthermore, the different protocols of electrotransfer led to different cell death outcomes, necrosis and apoptosis, as indicated by an annexin V and 7AAD assays. The obtained data provide new insights on the presence of cytosolic DNA sensors in tumor cells and the activation of different types of cells death after electrotransfer of pDNA. These observations have important implications on the planning of gene therapy or DNA vaccination protocols.

\section{INTRODUCTION}

Electroporation (EP) is a delivery method in which cells are exposed to electric pulses with specific intensities and durations in order to increase the permeability of the cell membrane, enabling transition of polar molecules into the cells. In biomedicine, this technique is widely used to transform bacteria and transfect eukaryotic cells and tissues [1]. Furthermore, this technique has reached clinical applications. In oncology, EP is used clinically to facilitate the entry of the chemotherapeutic agents bleomycin and cisplatin into the cells of several tumor types (electrochemotherapy or ECT), resulting in increased antitumor effectiveness of chemotherapeutic drugs leading to high percentage of complete tumor regressions [2-6]. Currently, ECT is performed in more than 140 cancer centers in Europe and is included in the national guidelines for treatment in UK, Germany, Slovenia and other EU countries. Another application of electroporation that has reached clinical trials is gene electrotransfer, where electroporation is used for transfection of cells within tissues with plasmid DNA (pDNA), generally for the 
purpose of cancer therapy, cancer vaccines, or infectious disease vaccines. In oncology, several clinical trials are ongoing for several types of cancer using pDNA encoding different therapeutic molecules, either immunomodulatory molecules such as interleukin-12 [7] or tumor associated antigens [8-11].

Although EP is used clinically, the electrical parameters for gene electrotransfer differ substantially depending on the therapeutic use. Tissue type, local or systemic type of expression as well as its duration, which are crucial for successful treatment outcomes, also affect the choice of electrical parameters for effective gene transfer. Currently, no universal pulse protocol exists for specific tissue applications, although three primary pulse protocols are used for tissue transfection. In the first, the same electrical parameters are used as in electrochemotherapy [12]. Plasmid delivery with this pulse protocol has reached tumor targeted clinical trials in the United States for melanoma [7], Merkel cell carcinoma [13], squamous cell carcinoma, and triple-negative breast cancer (ClinicalTrials.gov). In the second, electric pulses of lower amplitude and longer duration are used [14, 15]. This pulse type has reached clinical trials for muscle delivery [8]. Finally, a combination of high voltage and low voltage electric pulses can be utilized $[16,17]$. This combination of pulse types has reached clinical trials for intratumor delivery [18].

At the cellular level, the mechanisms of electrotransfer-mediated pDNA entry are not fully understood. After the exposure of the cell to electric pulses in the presence of pDNA, a DNA-membrane complex is formed on the membrane facing the cathode $[19,20]$, then this complex enters the cells via endocytosis [21] or macropinocytosis [22]. DNA escapes intracellular vesicles to enter the cell's nucleus to be transcribed then translated into the therapeutic protein. Only DNA that enters the cells via these mechanisms is transcribed, because inhibitors of endocytosis almost completely abrogate the expression of pDNA-encoded genes [23, 24].

In our previous study, we showed that the mRNAs and proteins of the receptors of the innate immune system that recognize foreign DNA (cytosolic DNA sensors) were upregulated after vector pDNA (plasmid backbone without therapeutic gene) electrotransfer in B16F10 melanoma cells [25]. This indicated that DNA is detected in the cytosol after endosomal escape or hypothetically it may also enter directly via electropores formed in the cell membrane [26-28]. Cytosolic DNA sensors are a subgroup of pattern recognition receptors (PRRs) and are activated by the abnormal presence of the DNA in the cytosol. Their activation leads to the upregulation of pro-inflammatory cytokines and chemokines, which may induce and inflammatory immune response. This activation can also lead to cell death [29-33]. In addition to upregulation of several cytosolic DNA sensors, in our previous studies, we showed increased cell death in vitro and complete regression of tumors in vivo [34, 35]. These effects were accompanied by increased production of interferon $\beta$ (IFN $\beta$ ) both in vitro and in vivo implicating paracrine-autocrine signaling leading to cell death [25].

Tumor regression and increased cell death in vitro have been demonstrated for other tumors such as sarcomas and carcinomas, and for tumor cell lines, following electrotransfer of pDNA devoid of therapeutic genes [36-45]. However, it is not known whether other tumor cell types of mesoderm origin (fibrosarcoma) and ectoderm origin (carcinoma) respond to pDNA electrotransfer in a manner similar to melanoma cells. Because the activation of immune system is important for planning and developing new treatment modalities for cancer, three different types of DNA electrotransfer pulse protocols were evaluated for potential upregulation of cytosolic DNA sensors and the downstream consequences of their activation, such as the production of pro-inflammatory molecules and induced cell death.

\section{RESULTS}

\section{Transfection efficiency, cytotoxicity and ATP levels}

Transfection efficiency, cell survival, and ATP levels were quantified after electrotransfer into TS/A and WEHI 164 cells using three different pulse protocols. The number of transfected cells, or transfection efficiency, was pulse protocol dependent. Pulse protocol EP2 produced a significantly higher transfection efficiency in both cell lines than the other pulse protocols, with $39.7 \pm$ $4.8 \%$ fluorescent cells in TS/A cell line and $74.9 \pm 0.8 \%$ in WEHI 164. Both the EP1 and EP3 pulse protocols transfected less than $10 \%$ of cells (Figure 1).

Although the transfection efficiency varied greatly between the pulse protocols, in TS/A cells no statistically significant changes in median fluorescence intensity between pulse protocols were observed. Whereas, in WEHI 164 cells, the fluorescence intensity of cells following transfection with the EP1 pulse protocol was statistically significantly higher than fluorescence intensity of cells transfected with the other two pulse protocols, indicating that although this pulse protocol is very cytotoxic (Figure 2), it enables higher numbers of plasmid copies to enter the cell's nucleus for expression.

The EP1 pulse protocol was less cytotoxic to TS/A cells (Figure 2A) than to WEHI 164 cells (Figure 2B); the application of EP1 pulses alone decreased the survival fraction by $49 \%$ in TS/A cells and $67 \%$ in WEHI 164 cells. Cell survival was less affected in either cell line after application of pulse protocols EP2 or EP3 alone (Figure $2 \mathrm{~A}, 2 \mathrm{~B})$. For pulse protocols EP1 and EP2, the addition of pDNA further decreased cell viability in a dose-dependent manner that was particularly detectable in WEHI 164 cells (Figure 2B). On the other hand, the addition of pDNA had no effect on cell survival after the application of the EP3 
pulse protocol; therefore, this protocol was not tested in subsequent experiments.

Thirty minutes after gWiz Blank electrotransfer with EP1 and EP2, ATP levels were measured (Figure 2C, 2D, Supplementary Table 2) to determine if the observed difference in the cytotoxic effects between electrotransfer pulse protocols was due to ATP leakage, which can cause cell necrosis.

A significant decrease in ATP levels was observed after pulse delivery. The decrease after EP1 pulse delivery alone was significantly greater than the decrease after EP2 pulses alone. The addition of pDNA further reduced ATP levels in cells using EP1 but not EP2 for delivery of pDNA $(p<0.05)$.

\section{Cell death mechanisms and morphology}

We investigated the mechanisms of cell death using pulse protocols EP1 and EP2. Differences in the level of apoptosis (early apoptosis) or necrosis (accompanied by late apoptosis) depended on the cell line and the electrotransfer protocol. In TS/A cells, both necrotic and apoptotic cells were detected with both EP pulse protocols 20 hours after electrotransfer of pDNA (Figure 2E); cell death was higher after EP1 pulses (Figure 2A). In WEHI 164 cells, we observed a greater number of apoptotic cells after pDNA electrotransfer using pulse protocol EP2 $(p<$ $0.05)$, and a greater number of necrotic cells after pDNA electrotransfer using pulse protocol EP1 $(p<0.05)$ (Figure $2 \mathrm{~F})$. These results were confirmed morphologically using Giemsa staining perfomed 6 hours after electrotranfer of pDNA (Supplementary Figures 1, 2). Several necrotic cells were observed after electrotransfer of pDNA using pulse protocol EP1 in both cell lines. Based on Giemsa staining, we confirmed that a greater quantity of apoptotic cells were produced after electrotransfer using the EP2 pulse protocol in WEHI 164 cells.

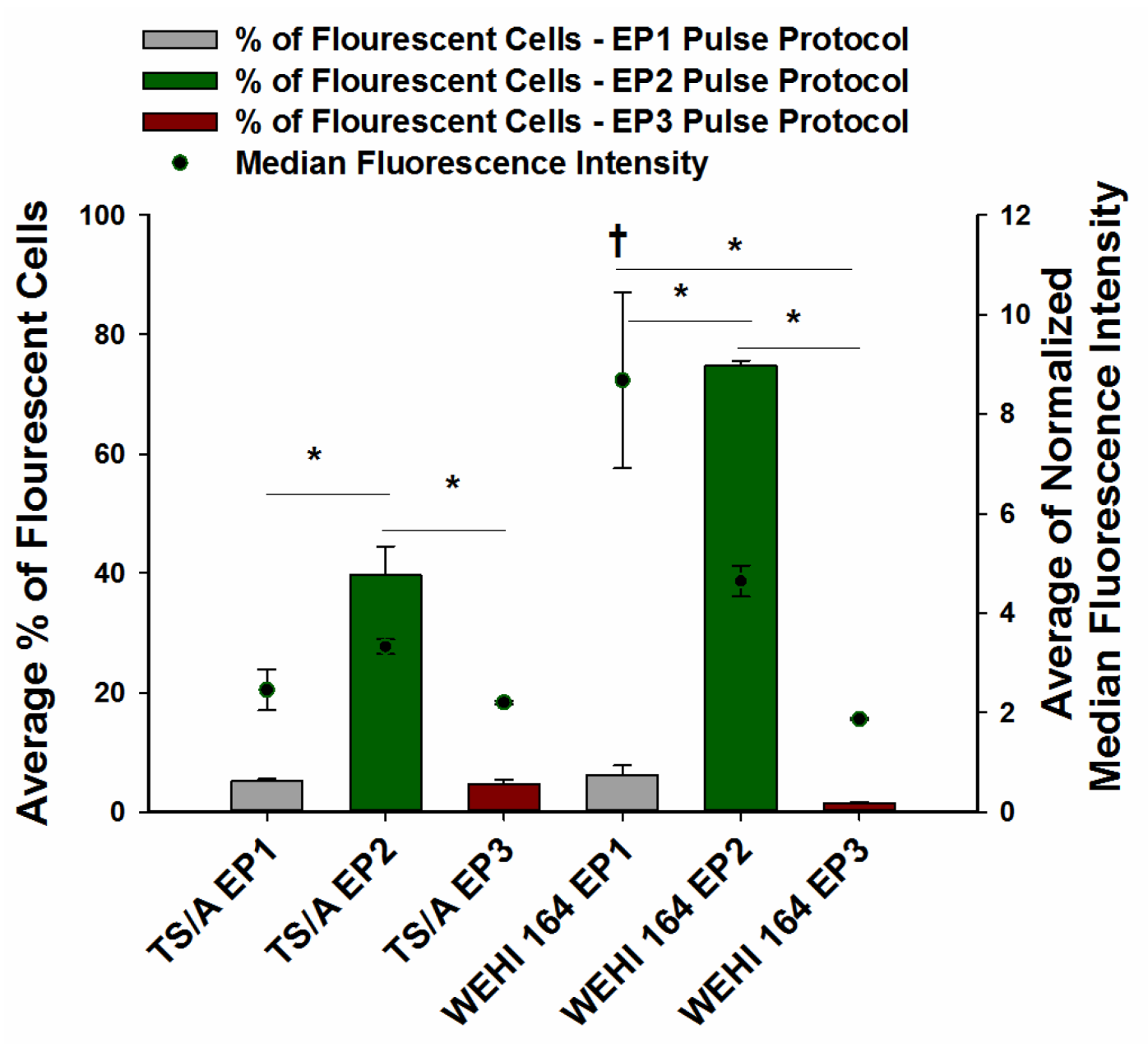

Figure 1: Transfection efficiency of TS/A and WEHI 164 cell lines after pEGFP-N1 electrotransfer using three different pulse protocols of DNA electrotransfer. pEGFP-N1 was electrotransfered by delivery of eight 5 ms pulses with a voltage to distance ratio of $600 \mathrm{~V} / \mathrm{cm}$, frequency $1 \mathrm{~Hz}(\mathrm{EP} 1)$, six $100 \mu$ s pulses with a voltage to distance ratio of $1300 \mathrm{~V} / \mathrm{cm}$, frequency $4 \mathrm{~Hz}$ (EP2) or with combination of one $100 \mu$ s pulse with a voltage to distance ratio $600 \mathrm{~V} / \mathrm{cm}$ and four $100 \mathrm{~ms}$ pulses with a voltage to distance ratio $80 \mathrm{~V} /$ $\mathrm{cm}$, duration, frequency $1 \mathrm{~Hz}(\mathrm{EP} 3)$ using plate electrode. "statistically significant difference of percentage of fluorescent cells between electrotransfer protocol groups $(P<0.05)$. 'Statistically significant difference between the mean values of median fluorescence intensity of cells receiving the EP1 protocol and fluorescence intensity of cells receiving the EP2 and EP3 pulse protocols. 


\section{Increased expression of DNA sensors depends on pulse protocol selection and cell type}

The mRNAs for several PRRs were detected in both TS/A (Table 1) and WEHI 164 cells (Table 2), while the mRNAs for toll-like receptor 9 (TLR9), retinoic acid inducible gene I (RIG1), and absent in melanoma 2 (AIM2) were not. SRY box 2 (SOX2) mRNA was detected in WEHI 164 but not TS/A cells. After vector pDNA electrotransfer, several DNA sensors were upregulated at the mRNA level. Increased expression of DDX60, DAI/
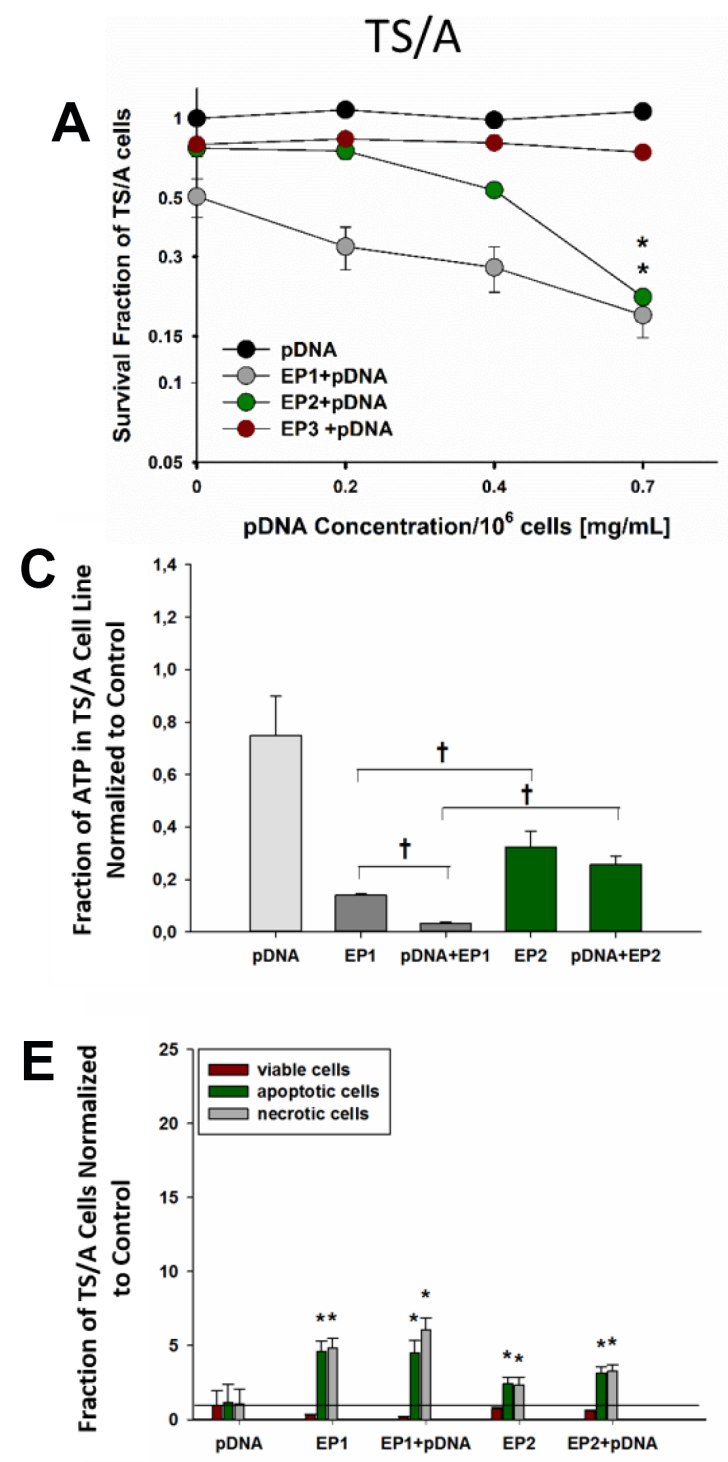

ZBP1 and p204 mRNAs occurred in both cell lines with variation in the level of expression depending on the cell line and the EP pulse protocol used (Tables 1,2). There were, however, differences between cell lines. DEAH (Asp-Glu-Ala-His) box helicase 36 (DHX36) was significantly upregulated in TS/A cells after pDNA delivery with EP1. The mRNAs for leucine-rich repeat flightless-interacting protein 1 (LRRFIP1), interferon activated gene 202 (p202), and p204 were minimally but significantly upregulated after pDNA delivery with EP2 in WEHI 164 cells.
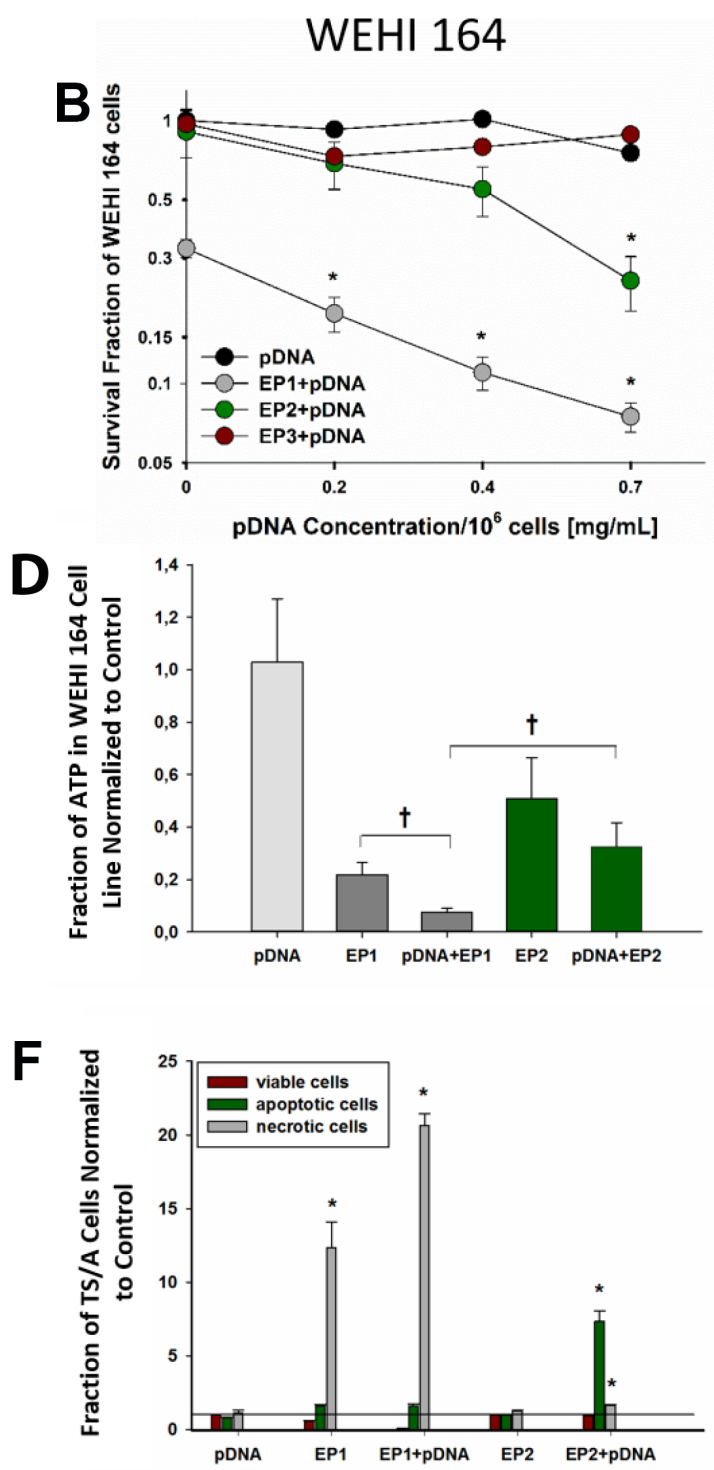

Figure 2: Cell survival, ATP level determination and cell death mechanism after electrotransfer in TS/A and WEHI 164 cell lines. Cell survival was measured 72 hours after electrotransfer of pDNA using the pulse protocols described in methods and Figure 1 in (A) TS/A cells and (B) WEHI 164 cells. The survival fraction was normalized to an unexposed control group. The concentrations on $\mathrm{X}$-axis represent final pDNA concentrations; $10 \mu \mathrm{g} / 10^{6}$ cells, $20 \mu \mathrm{g} / 10^{6}$ cells and $35 \mu \mathrm{g} / 10^{6}$ cells in $50 \mu 1$ of total volume, respectively. The percentage of ATP inside (C) TS/A and (D) WEHI 164 cells was determined immediately after electrotransfer. Cell death mechanisms were quantified in (E) TS/A and cells (F) WEHI 164 cells for the EP1 and EP2 electrotransfer protocols in the presence and absence of pDNA by flow cytometry for Annexin V and 7-AAD. *Statistically significant difference compared to different electrotransfer pulse protocol (EP) groups $(P<0.05)$. "statistically significant difference between indicated groups $(P<0.05)$. "statistically significant difference from pDNA group $(p<0.05)$. 
Table 1: Fold changes in mRNA levels of endosomal and cytosolic DNA sensors in TS/A tumor cells 4 hours after pDNA electrotransfer

\begin{tabular}{|c|c|c|c|c|c|c|c|c|c|c|c|c|c|c|c|c|}
\hline \multirow[t]{2}{*}{ TS/A } & \multicolumn{3}{|c|}{ control } & \multirow{2}{*}{$\begin{array}{l}\text { gWiz Blank } \\
\text { foldex } \pm \text { SE }\end{array}$} & \multicolumn{3}{|c|}{ EP1 } & \multicolumn{2}{|l|}{ EP2 } & \multicolumn{2}{|l|}{ EP3 } & \multicolumn{2}{|l|}{ pDNA+EP1 } & \multicolumn{2}{|l|}{ pDNA+EP2 } & pDNA+EP3 \\
\hline & $n$ & foldex $\pm S E$ & $n$ & & $n$ & foldex $\pm \mathrm{SE}$ & $n$ & foldex $\pm \mathrm{SE}$ & $n$ & foldex $\pm \mathrm{SE}$ & $n$ & foldex $\pm \mathrm{SE}$ & $n$ & foldex $\pm \mathrm{SE}$ & $n$ & foldex $\pm \mathrm{SE}$ \\
\hline TLR9 & 8 & 1 & 6 & l & 3 & I & 2 & I & 3 & / & 4 & I & 3 & I & 3 & I \\
\hline RIG-1 & 8 & I & 6 & / & 3 & l & 2 & / & 3 & / & 4 & I & 3 & I & 3 & l \\
\hline DDX60 & 9 & $1.2 \pm 0.3$ & 6 & $0.7 \pm 0.3$ & 4 & $0.7 \pm 0.2$ & 2 & $1.7 \pm 1.2$ & 3 & $0.8 \pm 0.0$ & 7 & $3.2 \pm 0.7^{*}$ & 5 & $4.0 \pm 0.9^{*}$ & 3 & $1.0 \pm 0.2$ \\
\hline DHX9 & 8 & $1.2 \pm 0.2$ & 6 & $0.3 \pm 0.1$ & 4 & $0.4 \pm 0.1$ & 2 & $1.7 \pm 1.2$ & 3 & $1.3 \pm 0.2$ & 4 & $0.1 \pm 0.0$ & 3 & $1.4 \pm 0.3$ & 3 & $0.8 \pm 0.1$ \\
\hline DHX36 & 9 & $1.3 \pm 0.4$ & 6 & $0.6 \pm 0.1$ & 4 & $0.9 \pm 0.3$ & 2 & $1.7 \pm 1.2$ & 3 & $0.9 \pm 0.1$ & 4 & $7.7 \pm 1.2^{*}$ & 5 & $1.9 \pm 1.0$ & 3 & $0.6 \pm 0.1$ \\
\hline AIM & 8 & I & 5 & I & 3 & I & 2 & I & 3 & I & 3 & I & 3 & l & 3 & I \\
\hline cGAS & 7 & $1.4 \pm 0.5$ & 5 & $1.1 \pm 0.3$ & 3 & $1.0 \pm 0.4$ & 2 & $1.9 \pm 1.1$ & 3 & $1.7 \pm 0.1$ & 3 & $1.6 \pm 0.6$ & 3 & $1.0 \pm 0.1$ & 3 & $1.1 \pm 0.1$ \\
\hline DAI/ZBP1 & 8 & $1.7 \pm 0.5$ & 4 & $1.5 \pm 1.2$ & 3 & $0.7 \pm 0.1$ & 2 & $1.7 \pm 1.2$ & 3 & $1.1 \pm 0.2$ & 5 & $14.1 \pm 3.9^{*}$ & 3 & $3.0 \pm 0.6^{*}$ & 3 & $1.0 \pm 0.1$ \\
\hline DDX41 & 6 & $1.1 \pm 0.2$ & 4 & $1.3 \pm 0.2$ & 3 & $1.6 \pm 0.4$ & 2 & $1.8 \pm 1.1$ & 3 & $1.2 \pm 0.2$ & 3 & $1.3 \pm 0.5$ & 3 & $1.3 \pm 0.2$ & 3 & $0.9 \pm 0.0$ \\
\hline LRRFIP1 & 6 & $0.8 \pm 0.1$ & 5 & $0.8 \pm 0.1$ & 3 & $1.1 \pm 0.2$ & 2 & $1.8 \pm 1.1$ & 3 & $1.2 \pm 0.1$ & 3 & $2.2 \pm 0.8$ & 3 & $2.8 \pm 1.2$ & 3 & $0.9 \pm 0.0$ \\
\hline P202 & 7 & $1.2 \pm 0.2$ & 5 & $0.8 \pm 0.3$ & 3 & $0.7 \pm 0.3$ & 2 & $1.7 \pm 1.2$ & 3 & $0.9 \pm 0.0$ & 3 & $2.8 \pm 1.0$ & 3 & $4.1 \pm 2.4$ & 3 & $1.0 \pm 0.1$ \\
\hline P204 & 3 & $1.0 \pm 0.2$ & 2 & $1.0 \pm 0.1$ & 2 & $0.6 \pm 0.1$ & 2 & $1.9 \pm 0.5$ & 3 & $1.2 \pm 0.1$ & 3 & $1.1 \pm 0.1$ & 3 & $3.4 \pm 0.3^{*}$ & 3 & $2.1 \pm 0.2^{*}$ \\
\hline SOX2 & 4 & I & 2 & l & & I & 2 & I & 2 & ' & 3 & I & 3 & I & 2 & I \\
\hline MRE1 & 4 & $1.2 \pm 0.2$ & 2 & $1.5 \pm 0.4$ & 2 & $0.8 \pm 0.1$ & 2 & $1.0 \pm 0.1$ & 2 & $0.6 \pm 0.0$ & 3 & $0.8 \pm 0.2$ & 3 & $0.9 \pm 0.1$ & 2 & $0.5 \pm 0.0$ \\
\hline Ku70 & 4 & $0.9 \pm 0.2$ & 2 & $1.0 \pm 0.1$ & 2 & $1.1 \pm 0.0$ & 2 & $0.8 \pm 0.1$ & 2 & $1.0 \pm 0.0$ & 3 & $1.0 \pm 0.1$ & 3 & $0.8 \pm 0.1$ & 2 & $1.0 \pm 0.0$ \\
\hline
\end{tabular}

Table 2: Fold changes in mRNA levels of endosomal and cytosolic DNA sensors in WEHI 164 tumor cells 4 hours after pDNA electrotransfer

\begin{tabular}{|c|c|c|c|c|c|c|c|c|c|c|c|c|c|c|c|c|}
\hline \multirow[t]{2}{*}{ WEHI 164} & \multirow[b]{2}{*}{$n$} & \multicolumn{2}{|l|}{ control } & \multicolumn{2}{|l|}{ gWiz Blank } & \multicolumn{2}{|l|}{ EP 1} & \multicolumn{2}{|l|}{ EP 2} & \multicolumn{2}{|l|}{ EP 3} & \multicolumn{2}{|l|}{ pDNA+EP1 } & \multicolumn{2}{|l|}{ pDNA+EP2 } & pDNA+EP3 \\
\hline & & foldex \pm SE & $n$ & foldex $\pm \mathbf{S E}$ & $n$ & foldex $\pm \mathrm{SE}$ & $n$ & foldex $\pm \mathrm{SE}$ & $n$ & foldex $\pm \mathrm{SE}$ & $n$ & foldex $\pm \mathrm{SE}$ & $n$ & foldex $\pm \mathrm{SE}$ & $n$ & foldex $\pm \mathbf{S E}$ \\
\hline TLR9 & 4 & I & 3 & I & 3 & I & 3 & I & 3 & l & 5 & I & 5 & I & 3 & I \\
\hline RIG-1 & 4 & I & 3 & I & 3 & l & 3 & / & 3 & l & 5 & l & 5 & I & 3 & I \\
\hline DDX60 & 4 & $1.0 \pm 0.1$ & 3 & $1.3 \pm 0.3$ & 3 & $1.4 \pm 0.2$ & 3 & $1.0 \pm 0.3$ & 3 & $0.4 \pm 0.1$ & 5 & $16.4 \pm 5.4^{\star}$ & 5 & $58.1 \pm 22.4^{*}$ & 3 & $1.9 \pm 0.2$ \\
\hline DHX9 & 4 & $1.1 \pm 0.3$ & 3 & $1.3 \pm 0.1$ & 3 & $1.8 \pm 0.4$ & 3 & $1.6 \pm 0.2$ & 3 & $0.8 \pm 0.1$ & 5 & $2.0 \pm 0.3$ & 5 & $1.0 \pm 0.2$ & 3 & $1.0 \pm 0.1$ \\
\hline DHX36 & 4 & $1.0 \pm 0.1$ & 3 & $1.4 \pm 0.5$ & 3 & $1.9 \pm 0.3$ & 3 & $1.3 \pm 0.1$ & 3 & $0.5 \pm 0.2$ & 5 & $1.0 \pm 0.4$ & 5 & $1.1 \pm 0.3$ & 3 & $0.7 \pm 0.1$ \\
\hline AIM & 4 & 1 & 3 & I & 3 & l & 3 & I & 3 & I & 5 & I & 5 & I & 3 & I \\
\hline cGAS & 4 & $1.0 \pm 0.1$ & 3 & $1.1 \pm 0.0$ & 3 & $2.4 \pm 0.3$ & 3 & $1.6 \pm 0.1$ & 3 & $1.0 \pm 0.1$ & 5 & $0.7 \pm 0.2$ & 5 & $1.2 \pm 0.4$ & 3 & $1.9 \pm 0.2$ \\
\hline DAI/ZBP1 & 4 & $1.0 \pm 0.2$ & 3 & $1.4 \pm 0.4$ & 3 & $1.4 \pm 0.3$ & 3 & $1.3 \pm 0.1$ & 3 & $0.5 \pm 0.0$ & 5 & $3.4 \pm 0.1^{*}$ & 5 & $27.2 \pm 1.8^{*}$ & 3 & $3.1 \pm 0.3^{*}$ \\
\hline DDX41 & 4 & $1.0 \pm 0.1$ & 3 & $1.1 \pm 0.2$ & 3 & $1.3 \pm 0.2$ & 3 & $1.1 \pm 0.1$ & 3 & $0.7 \pm 0.1$ & 5 & $1.5 \pm 0.3$ & 5 & $1.4 \pm 0.1$ & 3 & $0.9 \pm 0.1$ \\
\hline LRRFIP1 & 4 & $1.1 \pm 0.2$ & 3 & $1.2 \pm 0.3$ & 3 & $1.8 \pm 0.5$ & 3 & $1.8 \pm 0.1$ & 3 & $0.8 \pm 0.1$ & 5 & $1.5 \pm 0.1$ & 5 & $2.7 \pm 0.1^{*}$ & 3 & $1.0 \pm 0.2$ \\
\hline P202 & 4 & $1.0 \pm 0.2$ & 3 & $1.2 \pm 0.2$ & 3 & $1.5 \pm 0.3$ & 3 & $1.2 \pm 0.2$ & 3 & $0.9 \pm 0.1$ & 5 & $1.7 \pm 0.5$ & 5 & $3.7 \pm 0.3^{*}$ & 3 & $0.9 \pm 0.2$ \\
\hline P204 & 3 & $1.0 \pm 0.0$ & 3 & $1.3 \pm 0.2$ & 3 & $1.0 \pm 0.0$ & 3 & $1.0 \pm 0.1$ & 3 & $1.1 \pm 0.1$ & 3 & $2.5 \pm 0.7$ & 3 & $2.6 \pm 0.2^{*}$ & 3 & $1.3 \pm 0.2$ \\
\hline SOX2 & 3 & $1.0 \pm 0.3$ & 3 & $1.0 \pm 0.3$ & 2 & $1.0 \pm 0.3$ & 2 & $1.4 \pm 0.1$ & 2 & $0.4 \pm 0.0$ & 2 & $0.5 \pm 0.1$ & 2 & $0.5 \pm 0.2$ & 2 & $0.9 \pm 0.2$ \\
\hline MRE1 & 3 & $1.0 \pm 0.2$ & 3 & $0.9 \pm 0.2$ & 2 & $1.8 \pm 0.6$ & 2 & $0.9 \pm 0.0$ & 2 & $0.6 \pm 0.0$ & 2 & $1.1 \pm 0.1$ & 2 & $0.8 \pm 0.1$ & 2 & $1.0 \pm 0.1$ \\
\hline Ku70 & 3 & $1.0 \pm 0.2$ & 3 & $0.9 \pm 0.1$ & 2 & $1.9 \pm 0.7$ & 2 & $0.8 \pm 0.1$ & 2 & $0.8 \pm 0.0$ & 2 & $1.2 \pm 0.1$ & 2 & $0.7 \pm 0.1$ & 2 & $1.2 \pm 0.0$ \\
\hline
\end{tabular}

Legend: cGAS, cyclic guanosine monophosphate-adenosine monophosphate synthase; DAI/ZBP1, DNA-dependent activator of interferon regulatory factor; DDX41, DEAD (Asp-Glu-Ala-Asp) box polypeptide 41; DDX60, DEAD (Asp-Glu-Ala-Asp) box polypeptide 60; DHX9, DEAH (Asp-Glu-Ala-His)box helicase 9; DHX36, DEAH (Asp-Glu-Ala-His) box helicase 36; LRRFIP1, leucine-rich repeat flightless-interacting protein 1; p204, interferon activated gene 204; p202, interferon activated gene 202; MRE11, meiotic recombination 11 homolog, double strand break repair nuclease; SOX2, SRY (sex

determining region Y)-box 2; Ku70, Lupus Ku autoantigen protein p70"statistically significant difference compared to control group $(P<0.05)$; ND, not detected. 
Our previous study demonstrated that increased mRNA expression for particular PRRs can translate into increased protein levels in B16F10 melanoma cells in vitro [25]. Here, TS/A cells were exposed to electrical pulses using the EP1 or EP2 pulse protocols in the presence and in the absence of pDNA. When cleared cell lysates were analyzed by Western blotting, a significant decrease in DAI/ZBP-1 protein expression was observed in the EP1+pDNA experimental group (Figure 3A). This was quite unexpected, since mRNA levels for this protein were the most highly upregulated in this experimental group (Table 1).

Previous work from other groups showed that DAI/ZBP-1 resides in the cytosol with a diffuse, but partially granular-like pattern in HeLa and L929 cells $[46,47]$. Overexpressed proteins may form inclusion bodies that could be eliminated from the cell lysate during centrifugation. So, the final step of centrifugation was excluded from the lysate preparation protocol and, when the crude lysate was analyzed by Western blotting, significant upregulation of DAI/ZBP1 protein was observed in EP1+pDNA and, to the lesser extent, in EP2+ pDNA experimental groups (Figure 3B, 3C).

\section{Increased expression of IFN $\beta$ and TNF $\alpha$ after electrotransfer}

In each group receiving electrotransfer of $\mathrm{pDNA}$, a marker for DNA sensor activation, IFN $\beta$, was upregulated on the mRNA level in both cell types. (Figure 4A, 4B) In
TS/A cells, this upregulation of approximately 30 -fold was comparable between the two pulse protocols (Figure 5A). However, this increase was reflected in increased protein levels only after pDNA delivery using EP1 (Figure 4C). IFN $\beta$ upregulation was more marked in WEHI 164 cells (Figure 4B). In these cells, the increase in IFN $\beta$ protein levels, approximately 150-fold, was similar between the two pulse protocols (Figure 4D).

The mRNA of the inflammatory marker TNF $\alpha$ was upregulated and increased production of protein detected after electrotransfer of pDNA. Specifically, in $\mathrm{TS} / \mathrm{A}$ cells, the increase in mRNA and protein levels were observed only after electrotransfer of pDNA using EP1 pulse protocol (Figure 4A, 4B). In WEHI 164 cells, the mRNA of TNF $\alpha$ was upregulated after electrotransfer of pDNA with each pulse protocols (Figure 4B); however, production of TNF $\alpha$ protein was increased only after pDNA electrotransfer using EP1 pulse protocol (Figure 4D).

\section{Detection of mRNA IFN $\beta$ receptor (IFNAR1) and detection of TNF $\alpha$ receptor (TNFR1) by Immunohistochemistry in TS/A and WEHI 164 cell lines}

Type I interferon receptors are ubiquitously expressed in cells [48], which was confirmed with RT-PCR on the mRNA level in both cell lines (data not shown). Immunocytochemical staining of cells also confirmed that both cell lines express TNF $\alpha$ receptor (Figure 5B).
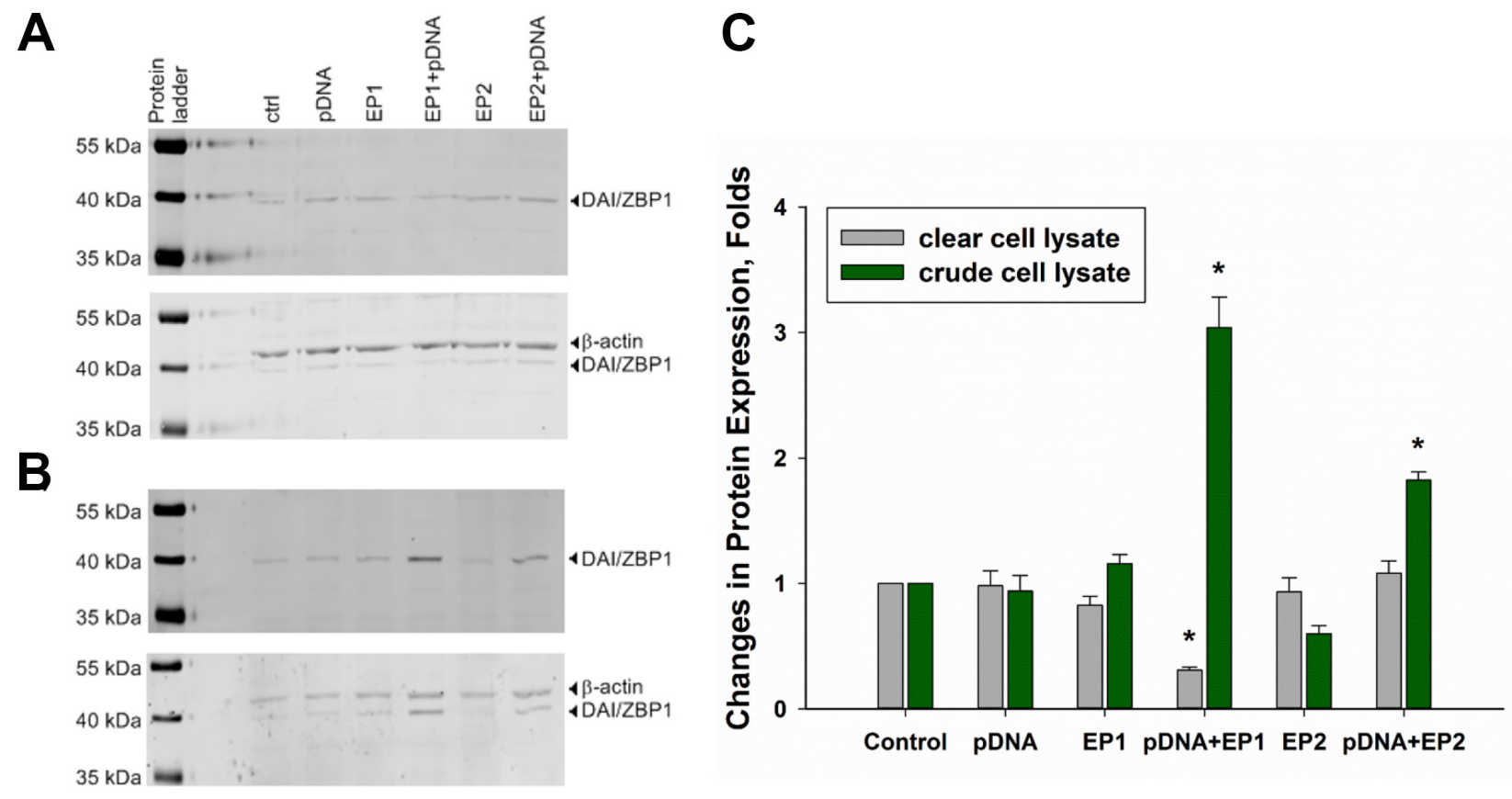

Figure 3: Changes in DAI/ZBP-1 expression in TS/A cells. Panel (A) shows Western blot analysis of DAI/ZBP1 expression among different experimental groups when cell lysate was cleared by centrifugation, while panel (B) shows the analysis of crude cell lysate. Panel (C) represents the results of 3 independent experiments (mean \pm standard error of the mean, $n=3$; open bars represent clear lysate, filled ones represent crude lysate, $\left.{ }^{* *} p<0.01 ;{ }^{*} p<0.05\right)$. 


\section{DISCUSSION}

The results of our study demonstrate that, in general, different gene electrotransfer pulse protocols that have different transfection efficiencies and produce different levels of immediate cell death can have similar effect on the expression of cytosolic DNA sensors in tumor cell lines. Although higher transfection efficiency was obtained in WEHI 164 cells, similar sensors (DAI/ZBP1, DDX60 and p204) were upregulated in two cell lines TS/A and WEHI 164 as in our previous study on B16F10 melanoma cells [49]. The EP1 protocol produced higher levels of IFN $\beta$ and TNF $\alpha$ in both cell lines than the EP2 protocol; these levels were higher in WEHI 164 than in TS/A cells. Finally, cell death can be induced by the electrotransfer of pDNA, with apoptosis prevalent in WEHI 164 after delivery with the EP2 protocol and necrosis prevalent after delivery with the EP1 protocol, while in TS/A cells both types of cell death occurred to the same level.

We initially determined transfection efficiency. Delivery with the EP2 pulse protocol led to a high

\section{A TS/A- MRNA}

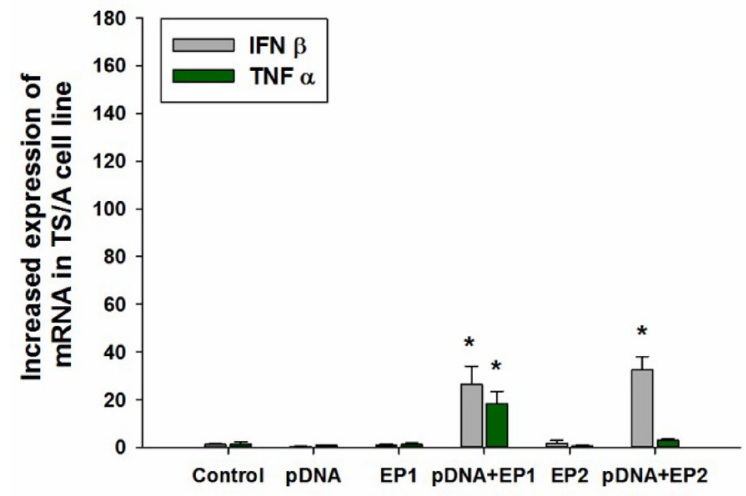

C TS/A-proteins

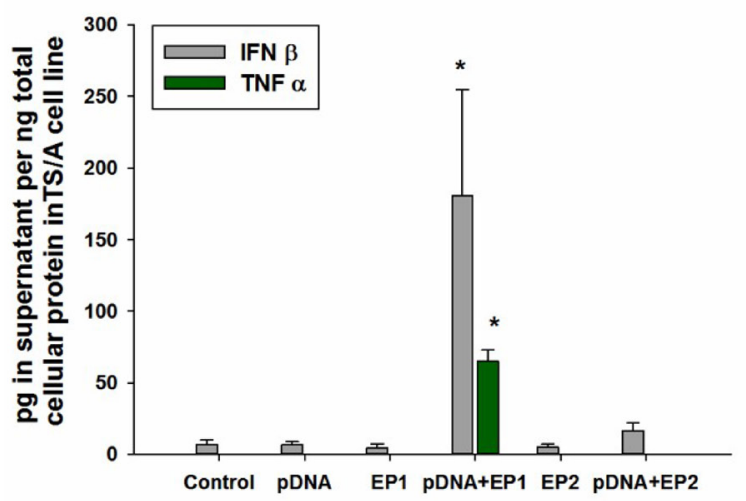

percentage of transfected cells of both cell lines, while pDNA delivery with the EP1 pulse protocol significantly increased only the median fluorescence intensity in WEHI 164 cells. This indicated that higher number of plasmid copies were introduced into the cells. Both types of pulse protocols were previously used in many studies in vitro and in vivo $[44,50-52]$. In vivo, in B16F10 mouse melanomas and P22 rat carcinomas, both pulse protocols yielded similar GFP expression, while in other tumor models (T24 human bladder carcinoma, SaF mouse sarcoma), the EP1 pulse protocol resulted in higher expression [53]. Many parameters pertinent to the tumor type, to the tumor microenvironment, to the pDNA and to the electrical parameters influence the transfection efficiency [17, 54-57]. Previous studies using a combination of short, high voltage and long, low voltage pulses showed a similar or even greater transfection efficiency in vivo in tissues compared to electrotransfer with EP1 and EP2 $[16,55,58,59]$. In vitro, the transfection efficiency using EP3 pulse protocol in Chinese hamster ovary cells was similar to that obtained

B WEHI 164- mRNA

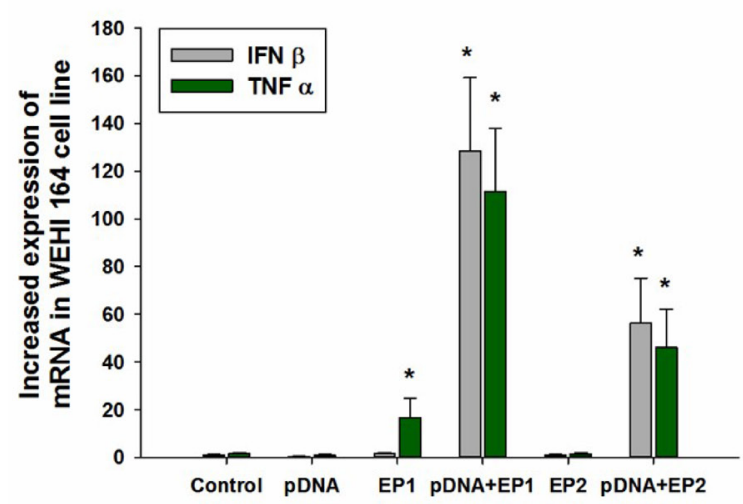

D WEHI 164- proteins

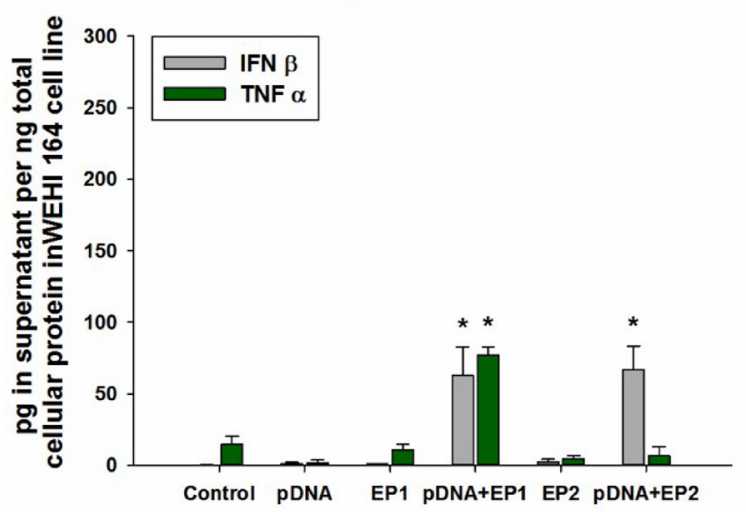

Figure 4: Effect of different electrotransfer pulse protocols on fold changes in mRNA and protein levels of INF $\beta$ and TNF $\alpha$. Levels of IFN $\beta$ and TNF $\alpha$ mRNA (A, B) were determined 4 hours after electrotransfer of vector pDNA using the pulse protocols described in methods and Figure 1. Intracellular levels of IFN $\beta$ and TNF $\alpha$ in the supernatant $(\mathbf{C}, \mathbf{D})$ were measured by ELISA 4 hours after electrotransfer. ${ }^{*}$ statistically significant difference compared to electrotransfer protocol only (EP) groups $(p<0.05)$. 
with high voltage alone [66]. In contrast, our results showed that this combined pulse protocol was not effective for in vitro transfection of WEHI 164 fibrosarcoma or TS/A carcinoma cells, although modifications of this pulse protocol may be more successful. The EP3 pulse protocol used in our study had the lowest effect on transfection efficiency $(<5 \%)$, DNA sensor mRNA upregulation $(<2$-fold) and cell survival $(>80 \%)$ of the pulse types tested. This pulse protocol clearly delivers DNA more effectively to cells in an in vivo environment $[16,58,60,61]$. In in vivo environments, high voltage pulses are crucial for efficient permeabilization of the membrane which enables transfection, while low voltage pulses provide electrophoretic force to pull negatively charged DNA molecules toward the cell membranes $[58,60]$. This was demonstrated for skin and muscle, while for tumors the separation of electrophoretic and permeabilization components did not result in improved transfection $[16,55]$. The same seems true for the selected cell lines, since the combination pulse regimen triggered only minimal DNA entry into the cell.

The higher transfection efficiency after delivery with the EP2 protocol indicated more efficient DNA uptake by an endocytosis-like mechanism [21, 22]. In TS/A cells, this higher transfection efficiency did not correlate with the upregulation of PRR mRNAs; both pulse protocols upregulated DDX60 and DAI/ZBP1, while the EP1 protocol additionally upregulated DHX36, and the EP2 protocol additionally upregulated p204. On the other hand, a correlation between higher transfection efficiency of EP2 protocol and larger number of

\section{A TS/A}

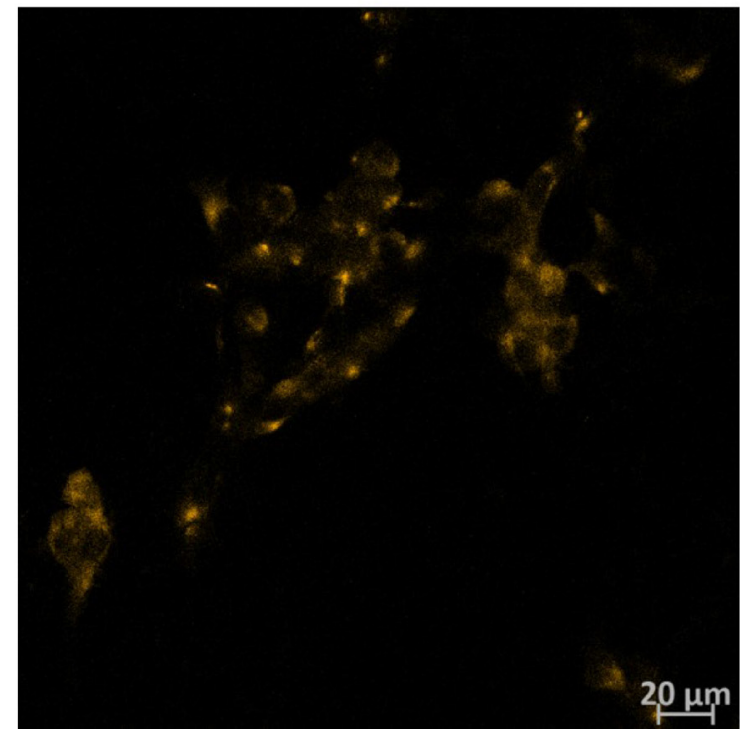

upregulated cytosolic DNA sensors was obtained in WEHI 164 cells. Delivery with pulse protocol EP3, combining one high voltage pulse with four low voltage pulses, only modestly transfected cells, had no effect on cell death and only minimally upregulated p204 in TS/A cells and DAI/ ZBP1 in WEHI 164 cells. The possible explanation for these observations could be different entry mechanisms for pDNA [28]. During electrotransfer, DNA enters the cell via an endocytosis-like mechanism $[21,22]$ but must escape the endosomes through the cytosol to the nucleus to be expressed. Early endosomal escape from the endosome to the nucleus can also occur [26]. Alternatively, DNA may be delivered directly to the cytosol through electropores formed in the plasma membrane $[27,28]$. Thus, due to the high transfection efficiency, higher cell survival, and pronounced upregulation of DNA sensors, the entry of pDNA with EP2 protocol is most probably endocytosis, while DNA entry following EP1 is more likely to be through electropores, although other groups demonstrated that endocytosis occurs after the use of EP1 pulses too $[21,22]$.

The pulse protocols used in our study were cytotoxic to both cell lines, even in the absence of pDNA. The most cytotoxic was EP1 protocol, followed by EP2 protocol, while EP3 only minimally reduced cell survival of TS/A cells. Nanosecond pulses can directly induce apoptosis through activation of mitochondrial signal pathways [62]. Alternatively, the destruction of the cell membrane by subnanosecond electric pulses can lead to necrosis [63]. Electric pulses with appropriate parameters can kill cancer cells directly through the induction of apoptosis without

B

WEHI 164

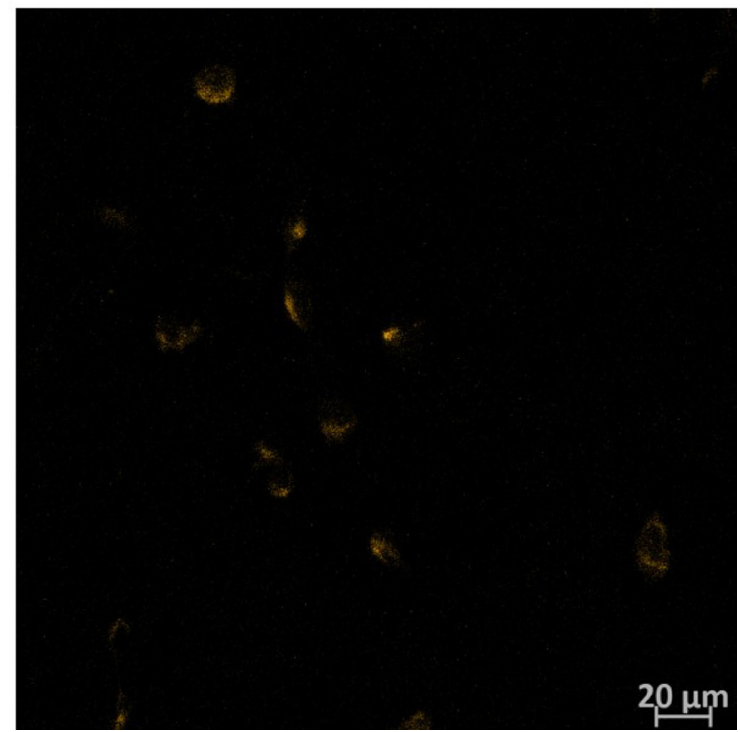

Figure 5: Immunohistochemistry of TNFR1 receptor in TS/A and WEHI 164 cell line. Cells were fixed with 4\% paraformaldehyde (A, B). Cells where receptor for TNF $\alpha$ (TNFR1) was present were stained in orange due to the Cy3-conjugated Donkey Anti-Rabbit IgG. 
chemical drugs [64]. In both cell lines, application of EP1 pulses were highly cytotoxic even in the absence of pDNA. This electrical cell damage is probably due to the too high electric fields that cause membrane damage resulting in electrolyte imbalance, influx of water, osmotic swelling of the cells and consequently cell death by necrosis $[63,65,66]$. Molecular dynamics simulations of electroporation in several lipid systems demonstrated that direct interaction between electric field and phospholipids exist [67]. Furthermore, in CHO cells, a direct interaction between the movement of membrane phosphatidylserine and electric field was demonstrated [68]. Thus, we can presume that the induction of necrosis following EP1 protocol is a physical process. Interestingly, $\mathrm{CHO}$ cells retained high viability using this pulse protocol, emphasizing the variation between cell lines [69].

Enhanced toxicity of the electric pulses in presence of the pDNA was reported in previous studies [70, 71]. In support of these observations, the cell death mechanism in response to the combination of pulses and DNA was both pulse protocol and pDNA dosage dependent (Figure 2), which is in agreement with our previous study [72], although there are differences in cell survival between the cell lines. Apoptosis was the major mechanism of cell death using the EP2 pulse protocol, while necrosis predominated when using the EP1 pulse protocol in WEHI 164 cells. In TS/A cells, both apoptosis and necrosis contributed equally to cell death. The cell morphology, which was assessed six hours after the therapy, demonstrated mainly necrotic cells death, while the data obtained by flow cytometry $20 \mathrm{~h}$ after therapy, demonstrated that both types of cell death occurred. This difference is due to the fact that apoptosis is a longer process than necrosis.

Cell death can also occur due to the loss of ATP after EP [73]. A significant reduction in intracellular ATP immediately after EP was demonstrated. This reduction was higher after the application of the EP1 pulse protocol than after the EP2 protocol. This reduction might indicate that more membrane damage was produced using long, low voltage pulses (EP1 pulse protocol) than short, high voltage pulses (EP2) (Figure 2). However, although the ATP loss was significant, it did not correlate with the reduction of cell survival, thus the obtained cell death could not be a direct consequence of the ATP loss that occurred within 30 minutes of electrotransfer.

The presence of foreign DNA in the cell can be detected by DNA sensors located in the cytosol or on the endosomal membrane. The activation of cytosolic DNA sensors takes place when these sensors detect and bind DNA in the cytosol [29-33]. Upon activation, these sensors induce the production of cytokines and potentially cell death. The upregulation of both endosomal and cytosolic DNA sensors was explored in our study. The results demonstrate that effective electrotransfer protocols have similar effects on the expression of DNA sensors, induce a cytokine response and produce cell death in vitro. Similar cytosolic DNA sensors were upregulated in TS/A murine mammary adenocarcinoma and WEHI 164 fibrosarcoma cells after effective electrotransfer protocols EP1 and EP2, confirming our previous study on B16F10 melanoma [72]. These results imply that many tumor cell types respond similarly to pDNA electrotransfer.

Although, in general, the basal levels of mRNA of the assayed PRRs were higher in TS/A cells, the upregulation was more pronounced in WEHI 164 cells (data not shown). The upregulation of DAI/ZBP1, DDX60, and p204 was detected previously in B16.F10 melanoma cells, and this was confirmed in TS/A mammary carcinoma cells. Basal levels of p204 mRNA were higher than those of DAI/ZBP1 and DDX60; however, the upregulation was more dramatic for DAI/ZBP1 and DDX60. This is similar to the results obtained by Zhu in Leydig cells, indicating that p204 may be the first sensor to respond to presence of DNA and that foreign DNA in the cytosol pronouncedly increased the expression of additional DNA sensors [74]. Interestingly, additional mRNAs were minimally yet significantly upregulated in WEHI 164 fibrosarcoma cells. Specifically, after delivery with the EP2 pulse protocol, LRRFIP1 and p202 were upregulated. Similar to DDX60 and DAI/ZBP1, these proteins are also known to activate IFN $\beta[75,76]$. Indeed, IFN $\beta$ mRNA and protein, markers for DNA sensor activation, were upregulated after pDNA electrotransfer. Following EP1 delivery, protein levels were similar between the cell types, while only WEHI 164 cells responded to delivery with EP2. Nearly every cell type expresses IFN receptor 1, IFNAR1 [48, 77], and as expected, both cell types express the mRNA for IFNRA1 (data not shown). This potentiates the possible autocrineparacrine effect, producing cell death.

Furthermore, upregulation of TNF $\alpha$ mRNA was observed in TS/A cells after DNA electrotransfer using EP1 pulse protocol or in WEHI 164 cells after any DNA electrotransfer or at low levels after exposure of cells to electric pulses alone. In WEHI 164 cells, mRNA levels did not consistently correlate to increased protein. TNF $\alpha$ protein was detected in either cell type only after delivery with EP1. While mRNA levels can predict protein levels, a lack of correlation is common [78].

Upregulation of DAI/ZBP1 mRNA in TS/A cells translated into upregulation on the protein level. The expression of DAI/ZBP1 was significantly increased after pDNA delivery with the EP1 protocol, and, to the lesser extent, the EP2 protocol when crude lysate containing all the cellular components was analyzed. Unexpectedly, the results obtained from cleared lysate containing only soluble proteins demonstrated a significant decrease of DAI/ZBP1 content after pDNA delivery with EP1 pulse protocol. These results lead to the suggestion that after pDNA delivery with the EP1 pulse protocol, which produces the lowest cell survival rate among the pulse protocols we applied, DAI/ZBP1 protein becomes 
so abundant that it forms insoluble inclusion bodies as overexpressed proteins do in many cases under unfavorable conditions. This suggestion leaves the open question of why the amount of DAI/ZBP1 is significantly decreased in clear extract after pDNA delivery with the EP1 pulse protocol. One possible explanation could be that after inclusion body formation, the expression of this protein slows, while protein molecules still present in the cytoplasm become less abundant due to common protein degradation processes. Additional study is required to investigate this possibility.
Upregulation of p204, DAI/ZBP1 and DDX60 activate signaling pathways that overlap and result in cytokine production that can lead to both apoptosis and necrosis [29, 79-83] (Figure 6). The cell death after electrotransfer of pDNA using the EP1 pulse protocol could be a consequence of the production of IFN $\beta$ and TNF $\alpha$. TNF $\alpha$ has shown an antitumor effect on tumor cells or tumors in combination with other treatments [84-88]. Cell lines that possess receptors for INF $\beta$ and/ or TNF $\alpha$ and receptor binding can activate necroptosis or apoptosis $[89,90]$. Necroptosis is a programmed form of

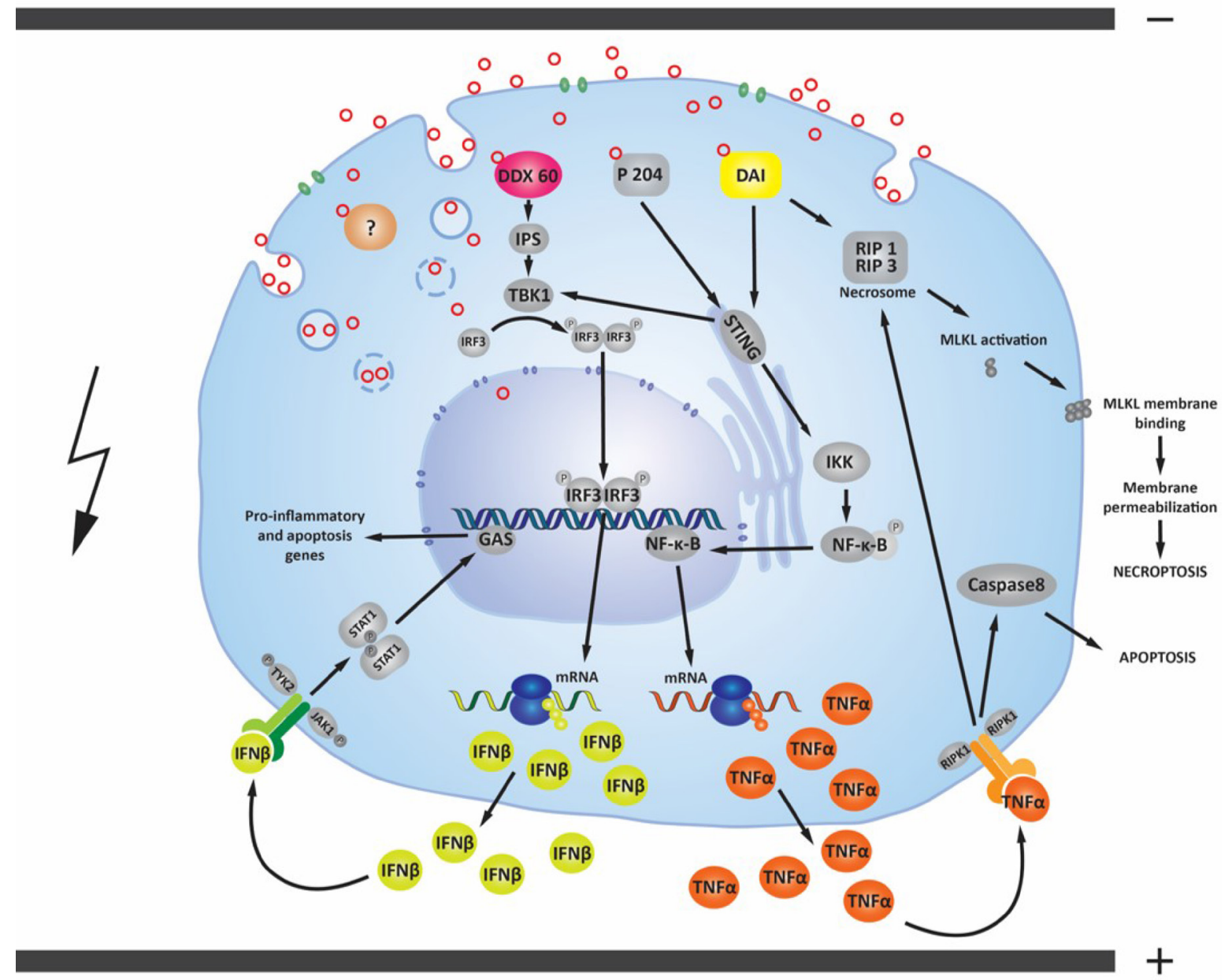

Figure 6: Possible signaling pathways activated by pDNA electrotransfer of tumor cells. After electrotransfer, pDNA (red circles) primarily enters the cell through endocytosis (blue circles). Plasmid DNA must undergo endosomal escape to enter the cytosol. Endosomal escape can occur early in the endocytosis process or later, before pDNA enters the nucleus [21, 26]. pDNA may possibly enter the cytosol directly via electropores formed in cell membrane [28]. The presence of pDNA inside the cytosol of different tumor cell lines is associated with the upregulation of cytosolic DNA sensors DDX60, DAI/ZBP1 and the p204 [44, 73, 74]. If these cytosolic DNA sensors are activated by binding pDNA, the transcription factor interferon regulator factor 3 (IRF3) is transported from the cytosol to the nucleus to induce transcription of IFN $\beta$ and other genes $[29,47,82,98]$. The upregulated and secreted IFN $\beta$ protein may bind to its cell-surface receptor(s) in an autocrine or paracrine fashion, leading to transcription of pro-inflammatory and apoptotic genes. The DNA sensors p204 and DAI/ZBP1 can activate a signaling pathway which leads to the nuclear translocation of the transcription factor NF- $\mathrm{KB}$ and consequently to transcription of pro-inflammatory cytokines, such as TNF $\alpha$, which is secreted from the cell $[29,47,80,81,99]$. TNF $\alpha$ may bind to cell-surface receptors, which leads to the activation of two different death mechanisms (apoptosis or necroptosis) [90]. Another signaling pathway of the cytosolic DNA sensor DAI/ZBP1 leads directly to necroptosis through MLKL activation [100]. Cytosolic DNA sensors and their signaling pathways described here are present and upregulated in mouse TS/A adenocarcinoma cells, mouse WEHI 164 fibrosarcoma cells, and mouse B16F10 melanoma cells [25]. Other DNA sensors, whether upregulated, not upregulated, or as yet undiscovered (labeled with "?") may also influence these signaling pathways. 
necrosis that requires the proteins RIPK3, MLKL, DAI/ ZBP1 and it is induced by death receptors, interferons, toll-like receptors, intracellular RNA and DNA sensors $[91,92]$. Otherwise, the features of necroptosis such as disruption of cell membrane and loss of organelles are the same as necrosis. Therefore, these death processes cannot be morphologically distinguished. To confirm that TS/A and WEHI 164 cells might respond in an autocrine or paracrine action to the production of IFN $\beta$ and TNF $\alpha$ proteins, the presence of IFN receptor (IFNAR1) and TNF $\alpha$ receptor (TNFR1) were confirmed in both cell lines. In TS/A cells, cell death due to the combination of apoptosis and necrosis was observed, in WEHI 164 cells, a higher level of necrosis was observed after DNA delivery with both pulse protocols. Binding of proteins IFN $\beta$ and $\mathrm{TNF} \alpha$ to their receptors could contribute to different cell death mechanisms after DNA electrotransfer.

\section{MATERIALS AND METHODS}

\section{Cell lines}

TS/A murine mammary adenocarcinoma cells [93] were cultured in advanced minimum essential medium (AMEM, Gibco, Thermo Fisher Scientific, Waltham, MA, USA) supplemented with $5 \%$ fetal bovine serum (FBS, Gibco) in $5 \% \mathrm{CO}_{2}$ humidified atmosphere at $37^{\circ} \mathrm{C}$. The cell line was tested for authentication in 2017 at IDDEx Bioresearch laboratory. WEHI 164 murine fibrosarcoma cells (ATCC CRL-1751, American Type Culture Collection, Manassas, VA, USA) were cultured in Roswell Park Memorial Institute Medium (RPMI-1640, Gibco) supplemented with 5\% fetal bovine serum (FBS, Gibco) in $5 \% \mathrm{CO}_{2}$ humidified atmosphere at $37^{\circ} \mathrm{C}$.

\section{Plasmids}

The vector plasmid gWiz Blank was commercially prepared (Aldevron, Fargo, ND, USA) at concentration of 2 $\mathrm{mg} / \mathrm{ml}$ in physiological saline. Additionally, concentrations of $1 \mathrm{mg} / \mathrm{ml}$ by further dilution and $3.5 \mathrm{mg} / \mathrm{ml}$ by concentration (Concentrator plus, Eppendorf, Hamburg, Germany) were prepared.

Plasmid EGFP-N1 (pEGFP-N1, BD Biosciences, San Jose, CA, USA), encoding green fluorescent protein, was used for transfection efficiency experiments. It was isolated after amplification in a competent Escherichia coli (TOP10; Thermo Fisher Scientific) using Maxi-Endo Free Plasmid Kits (Qiagen, Hilden, Germany) according to the manufacturer's instructions. The concentration of isolated plasmid was measured with Epoch Microplate Spectrophotometer (BioTek Instruments, Winooski, VT, USA).

\section{DNA Electrotransfer pulse protocols}

Cells were prepared and processed as previously described [94]. Fifty $\mu \mathrm{L}$ containing $20 \mu \mathrm{g}$ pDNA per $1 \times 10^{6}$ cells was pipetted between two electrodes with $2 \mathrm{~mm}$ gap and three different electric pulse protocols were applied: EP1 ( 8 pulses, $600 \mathrm{~V} / \mathrm{cm}, 5 \mathrm{~ms}$ duration at frequency $1 \mathrm{~Hz}$ ), EP2 (6 pulses, $1300 \mathrm{~V} / \mathrm{cm}, 100 \mu \mathrm{s}$ duration at frequency $4 \mathrm{~Hz}$ ) and EP3 $(1$ pulse $600 \mathrm{~V} / \mathrm{cm}$, $100 \mu$ s duration +4 pulses $80 \mathrm{~V} / \mathrm{cm}, 100 \mathrm{~ms}$ duration, frequency $1 \mathrm{~Hz}$ ). The cells were then incubated in AMEM or RPMI in 6-cm Petri dishes (Corning Incorporated, Corning, NY, USA) for determination of transfection efficiency, Adenosine triphosphate (ATP) leakage and cell death mechanism and in ultralow attachment 6- well or 24well plates (Corning Incorporated) for cell survival assays, determination of morphological changes and expression of DNA sensors and selected cytokine mRNA and protein.

\section{Transfection efficiency}

Two days after electrotransfer with $10 \mu \mathrm{g}$ pEGFP-N1 per $1 \times 10^{6}$ cells, the cells were imaged by fluorescence microscopy (Olympus IX-70, Hamburg, Germany), then trypsinized and resuspended in $400 \mu \mathrm{l}$ of PBS for flow cytometry analysis (FACSCanto II flow cytometer, BD Biosciences). A 488-nm laser (air-cooled, $20 \mathrm{~mW}$ solid state) and 530/30-nm band-pass filter were used for the excitation and detection of green fluorescent protein fluorescence, respectively. A total of 20,000 events were measured. The percentage of transfected cells represented transfection efficiency, while the fluorescence intensity was determined as an indirect measure of the amount of pDNA that was introduced into the cells [95].

\section{Cell survival assay}

Cell survival was determined 72 hours after electrotransfer [96] of $10 \mu \mathrm{g}, 20 \mu \mathrm{g}$, and $35 \mu \mathrm{g} \mathrm{gWiz}$ Blank per $1 \times 10^{6}$ cells. After electrotransfer, $1 \times 10^{3}$ cells were incubated in $0.1 \mathrm{ml}$ AMEM in 96-well plates (Corning Incorporated) at $37^{\circ} \mathrm{C}$ in a $5 \% \mathrm{CO}_{2}$ humidified incubator. The viability of the cells after pulse delivery was determined using Presto Blue (Thermo Fisher Scientific) per manufacturer's instructions and normalized to the viability of control cells that were not exposed to electric field.

\section{ATP determination assay}

Thirty minutes after electrotransfer of gWiz Blank, $1 \times 10^{6}$ cells were incubated in $1 \mathrm{ml}$ of appropriate media for $1 \mathrm{~h}$ at $37^{\circ} \mathrm{C}$ at $5 \% \mathrm{CO}_{2}$. The cells were centrifuged (Heraeus Fresco 21 centrifuge, Thermo Fisher Scientific) for 10 minutes at $12000 \mathrm{~g}$. The supernatant was removed, and the cell pellets were resuspended in $1 \mathrm{ml}$ of boiling 
distilled water, vortexed, immediately placed on ice, and centrifuged for 5 minutes at $4^{\circ} \mathrm{C}$ and $21000 \mathrm{~g}$. The samples were transferred to the white 96-well plates and ATP content was determined (ATP determination kit, Molecular Probes, Thermo Fisher Scientific) according to manufacturer's instructions.

\section{Expression of PRRs and selected cytokines}

Four hours after gWiz Blank electrotransfer with pulse protocols EP1, EP2 and EP3, total RNA was isolated from $1 \times 10^{6}$ cells, cDNA was synthesized and diluted 1:10. Relative mRNA levels were determined with quantitative RT-PCR using IDT Oligonucleotides (IDT, Coralville, IA, USA) (Supplementary Table 1) and Syber Select Maste Mix (Thermofisher scientific).

\section{ELISA}

Four hours after electrotransfer with gWiz Blank, cell cultures were washed with PBS, lysed (Mammalian Protein Extraction Buffer, GE Healthcare, Piscataway, NJ, USA), and total protein quantified by BCA assays (Pierce Biotechnology, Rockford, IL, USA). IFN $\beta$ was measured by ELISA (PBL Assay Science, Piscataway, NJ, USA) in normalized cell culture lysates. Tumor necrosis factor $\alpha$ (TNF $\alpha$ ) was measured by ELISA (Ray Biotech, Norcross, GA, USA) in cell culture supernatants and then normalized to the total protein levels in the lysates to account for differences in cell number and viability.

\section{Western blot analysis}

TS/A cells were electrotransfected with gWiz Blank plasmid as described above using EP1 and EP2 pulse protocols. The cells were then seeded into low-attachment 6-well plates (Corning Incorporated, Corning, NY, USA) and incubated for 9 hours. After incubation, the cells were lysed using RIPA buffer in accordance with the manufacturer's protocol (Santa Cruz Biotechnology Inc., Dallas, TX, USA). For the preparation of crude lysate, the final centrifugation step was excluded. Total protein content was determined using a Pierce BCA Protein Assay Kit (Fisher Scientific) then adjusted with RIPA buffer. Twenty-five $\mu \mathrm{g}$ or $40 \mu \mathrm{g}$ of total protein (for cleared and crude lysate, respectively) per well was separated in a $10 \%$ polyacrylamide gel, transferred onto nitrocellulose membrane (Bio-Rad, Hercules, CA), blocked for 1 hour in $5 \%$ milk in TBS Tween-20 buffer (Fisher Scientific) and incubated overnight at $4^{\circ} \mathrm{C}$ with primary antibodies: rabbit anti-DAI/ZBP1 or rabbit anti- $\beta$-actin as a loading control (Fisher Scientific). After washing with TBS Tween-20 buffer, the membrane was probed with Alexa Fluor 680 goat anti-rabbit secondary antibody (Fisher Scientific) for $45 \mathrm{~min}$ at room temperature, washed and protein bands were visualized with Odyssey Infrared Imaging System
(LI-COR, Inc., Lincoln, NE, USA). The band intensity was quantified using Image J software [97].

\section{Morphological changes of tumor cells after DNA electrotransfer}

Six hours after electrotransfer of gWiz Blank, $1 \times 10^{3}$ cells in $80 \mu \mathrm{l}$ of PBS were transferred to a slide chamber and centrifuge at $123 \mathrm{~g}$ for 4 minutes (Cytospin 2, Thermo Shandon, Runcorn, UK). The slides were air dried then stained with Giemsa's Azure methylene blue solution (Merck, Darmstadt, Germany) according to the manufacturer's protocol. Images of cell morphological changes were captured with a DP72 CCD camera using Olympus BX-51 microscope (Olympus, Tokio, Japan). Necrotic cells were characterized as eosinophilic cells or as cell ghosts without the presence of nucleus, while apoptotic cells characteristics included cytoplasmic shrinkage, nuclear condensation, nuclear fragmentation and the formation of apoptotic bodies.

\section{Determination of cell death mechanisms}

Based on our previous results [49], cell death mechanism was determined twenty hours after electrotransfer of gWiz Blank by FITC Annexin V Apoptosis Detection Kit with 7-AAD (7-Aminoactinomycin D) (BioLegend, San Diego, CA, USA) according to manufacturer's instructions for flow cytometric analysis (FACSCanto II, BD Biosciences). A total of 20,000 events were measured. Apoptosis was evaluated by phosphatidylserine detection in the outer plasma membrane leaflet using Annexin V. Necrotic cells were detected with 7-AAD, which has a high DNA-binding constant and can pass into the nucleus and bind to DNA in necrotic cells.

\section{Immunohistochemistry of TNFR1 receptor}

$1 \times 10^{5}$ cells were plated in each well of $\mu$-Chamber 12 well glass slides (Ibidi, Munich, Germany). After 24 hours the cells were fixed with $4 \%$ paraformaldehyde. Then, the cells were stained immunohistochemically using primary Anti-TNF Receptor I antibody (Abcam, Cambridge, MA, USA) and Cy3-conjugated AffiniPure Donkey Anti-Rabbit IgG as a secondary antibody (Jackson Immuno Research, PA, USA).

\section{Statistical analysis}

For most experiments, statistical analysis was performed by SigmaPlot 12.0 (Systac Software Inc., San Jose, CA, USA). Statistical evaluation was made by oneway analysis of variance (one-way ANOVA). Western blot results were analyzed by one-way ANOVA with HolmSidak test. A $p$-value of less than 0.05 was considered statistically significant. ELISA results were analyzed 
by two-way ANOVA with Tukey-Kramer multiple comparisons test (GraphPad Software, La Jolla, CA, USA). A $p$-value less than 0.05 was considered significant.

\section{CONCLUSIONS}

We have shown presence of cytosolic DNA sensors in different tumor cell lines and the upregulation of several sensors after pDNA electrotransfer. This upregulation correlates with the expression of IFN $\beta$ and TNF $\alpha$ genes and proteins. The expression of cytosolic DNA sensors is pulse protocol dependent, as is the mechanism of cell death. These effects may be due to both electrical cell damage, which occurs immediately after application of electric pulses, and to the induction of apoptosis or necrosis through activation of cytosolic DNA sensors.

\section{Abbreviations}

AIM2: Absent in melanoma 2; ATP: Adenosine triphosphate; cGAS: Cyclic guanosine monophosphateadenosine monophosphate synthase; DAI/ZBP1: DNAdepended activator of interferon regulatory factor/ Z-DNA binding protein 1; DDX41: DEAD (Asp-GluAla-Asp) box polypeptide 41; DDX60: DEAD (AspGlu-Ala-Asp) box polypeptide 60; DHX36: DEAH (Asp-Glu-Ala-His) box helicase 36; DHX9: DEAH (AspGlu-Ala-His) box helicase 9; ECT: Electrochemotherapy; ELISA: Enzyme-linked immunosorbent assay; EP: Electroporation; EP1: Electroporation pulse protocol one $(8$ pulses, $600 \mathrm{~V} / \mathrm{cm}, 5 \mathrm{~ms}$ duration at frequency 1 $\mathrm{Hz}$ ); EP2: Electroporation pulse protocol two (6 pulses, $1300 \mathrm{~V} / \mathrm{cm}, 100 \mu$ s duration at frequency $4 \mathrm{~Hz}$ ); EP3: Electroporation pulse protocol three $(1$ pulse $600 \mathrm{~V} / \mathrm{cm}$, $100 \mu$ s duration +4 pulses $80 \mathrm{~V} / \mathrm{cm}, 100 \mathrm{~ms}$ duration, frequency 1Hz); IFNAR1: Interferon alpha/beta receptor 1; IFN $\beta$ : Interferon $\beta$; Ku70: Lupus $\mathrm{Ku}$ autoantigen protein p70; LRRFIP1: Leucine-rich repeat flightlessinteracting protein 1; MRE11: Meiotic recombination 11 homolog, double strand break repair nuclease; ND: Not detected; p202: Interferon activated gene 202; p204: Interferon-inducible protein 204; pDNA: Plasmid DNA; pEGFP-N1: Plasmid for enhanced green fluorescent protein; PRR: Pattern recognition receptors; RIG I: Retinoic acid inducible gene I; RT-PCR: Real time reverse transcription polymerase chain reaction; SOX2: SRY (sex determining region Y)-box 2; TLR9: Toll-like receptor 9; TNFR1 -Tumor necrosis factor receptor 1; TNF $\alpha$ : Tumor necrosis factor $\alpha$.

\section{Author contributions}

Conceptualization: L.H. and M.C; Methodology: K.Z., M.B, N.S, O.P, L.H and M.C; Investigation: K.Z., M.B, N.S. and L.H.; Writing - Original Draft: K.Z.; Writing -Review \& Editing: M.B, N.S, L.H and M.C.; Funding: L.H. and M.C;
Acquisition: K.Z., M.B, N.S, O.P, L.H and M.C.; Resources: L.H and M.C.; Supervision: L.H. and M.C.

\section{ACKNOWLEDGMENTS}

We would like to thank Mira Lavric and colleagues from the Cytopathology Department for their help with cell cultures and flow cytometry measurements (Institute of Oncology Ljubljana, Ljubljana, Slovenia).

\section{CONFLICTS OF INTEREST}

Authors do not have any conflicts of interests.

\section{FUNDING}

Research reported in this publication was supported by the National Cancer Institute of the National Institutes of Health under award number R01CA196796. The content is solely the responsibility of the authors and does not necessarily represent the official views of the National Institutes of Health.

\section{REFERENCES}

1. Teissie J, Golzio M, Rols MP. Mechanisms of cell membrane electropermeabilization: A minireview of our present (lack of?) knowledge. Biochim Biophys Acta. 2005;1724:270-80. https://doi.org/10.1016/j.bbagen.2005.05.006.

2. Mali B, Jarm T, Snoj M, Sersa G, Miklavcic D. Antitumor effectiveness of electrochemotherapy: a systematic review and meta-analysis. Eur J Surg Oncol. 2013; 39:4-16. https:// doi.org/10.1016/j.ejso.2012.08.016. PMID:22980492.

3. Miklavčič D, Mali B, Kos B, Heller R, Serša G. Electrochemotherapy: from the drawing board into medical practice. Biomed Eng Online. 2014; 13:29. https://doi. org/10.1186/1475-925X-13-29.

4. Edhemovic I, Brecelj E, Gasljevic G, Marolt Music M, Gorjup V, Mali B, Jarm T, Kos B, Pavliha D, Grcar Kuzmanov B, Cemazar M, Snoj M, Miklavcic D, et al. Intraoperative electrochemotherapy of colorectal liver metastases. J Surg Oncol. 2014; 110:320-27. https://doi. org/10.1002/jso.23625.

5. Campana LG, Clover AJ, Valpione S, Quaglino P, Gehl J, Kunte C, Snoj M, Cemazar M, Rossi CR, Miklavcic D, Sersa G. Recommendations for improving the quality of reporting clinical electrochemotherapy studies based on qualitative systematic review. Radiol Oncol. 2016; 50:1-13. https://doi.org/10.1515/raon-2016-0006.

6. Bertino G, Sersa G, De Terlizzi F, Occhini A, Plaschke CC, Groselj A, Langdon C, Grau JJ, McCaul JA, Heuveling D, Cemazar M, Strojan P, de Bree R, et al. European Research on Electrochemotherapy in Head and Neck Cancer (EURECA) project: results of the treatment of skin cancer. 
Eur J Cancer. 2016; 63:41-52. https://doi.org/10.1016/j. ejca.2016.05.001.

7. Daud AI, DeConti RC, Andrews S, Urbas P, Riker AI, Sondak VK, Munster PN, Sullivan DM, Ugen KE, Messina JL, Heller R. Phase I trial of interleukin-12 plasmid electroporation in patients with metastatic melanoma. J Clin Oncol. 2008; 26:5896-903. https://doi.org/10.1200/ JCO.2007.15.6794.

8. Low L, Mander A, McCann K, Dearnaley D, Tjelle T, Mathiesen I, Stevenson F, Ottensmeier CH. DNA vaccination with electroporation induces increased antibody responses in patients with prostate cancer. Hum Gene Ther. 2009; 20:1269-78. https://doi.org/10.1089/hum.2009.067.

9. Diaz CM, Chiappori A, Aurisicchio L, Bagchi A, Clark J, Dubey S, Fridman A, Fabregas JC, Marshall J, Scarselli E, La Monica N, Ciliberto G, Montero AJ. Phase 1 studies of the safety and immunogenicity of electroporated HER2/CEA DNA vaccine followed by adenoviral boost immunization in patients with solid tumors. J Transl Med. 2013; 11:62. https://doi.org/10.1186/1479-5876-11-62.

10. Trimble CL, Morrow MP, Kraynyak KA, Shen X, Dallas M, Yan J, Edwards L, Parker RL, Denny L, Giffear M, Brown AS, Marcozzi-Pierce K, Shah D, et al. Safety, efficacy, and immunogenicity of VGX-3100, a therapeutic synthetic DNA vaccine targeting human papillomavirus 16 and 18 E6 and E7 proteins for cervical intraepithelial neoplasia 2/3: a randomised, double-blind, placebo-controlled phase $2 \mathrm{~b}$ trial. Lancet. 2015; 386:2078-88. https://doi.org/10.1016/ S0140-6736(15)00239-1.

11. Heller R, Heller LC. Gene electrotransfer clinical trials. Adv Genet. 2015; 89:235-62. https://doi.org/10.1016/ bs.adgen.2014.10.006.

12. Heller R, Jaroszeski M, Atkin A, Moradpour D, Gilbert $\mathrm{R}$, Wands J, Nicolau C. In vivo gene electroinjection and expression in rat liver. FEBS Lett. 1996; 389:225-28. https://doi.org/10.1016/0014-5793(96)00590-X.

13. Miller NJ, Bhatia S, Parvathaneni U, Iyer JG, Nghiem P. Emerging and mechanism-based therapies for recurrent or metastatic Merkel cell carcinoma. Curr Treat Options Oncol. 2013; 14:249-63. https://doi.org/10.1007/ s11864-013-0225-9.

14. Pavlin D, Cemazar M, Sersa G, Tozon N. IL-12 based gene therapy in veterinary medicine. J Trans1 Med. 2012; 10:234. https://doi.org/10.1186/1479-5876-10-234.

15. Shirley SA, Lundberg CG, Li F, Burcus N, Heller R. Controlled gene delivery can enhance therapeutic outcome for cancer immune therapy for melanoma. Curr Gene Ther. 2015; 15:32-43. https://doi.org/10.2174/156652321466614 1121111630 .

16. André FM, Gehl J, Sersa G, Préat V, Hojman P, Eriksen J, Golzio M, Cemazar M, Pavselj N, Rols MP, Miklavcic D, Neumann E, Teissié J, Mir LM. Efficiency of high- and low-voltage pulse combinations for gene electrotransfer in muscle, liver, tumor, and skin. Hum Gene Ther. 2008; 19:1261-71. https://doi.org/10.1089/hum.2008.060.

17. Lambricht L, Lopes A, Kos S, Sersa G, Préat V, Vandermeulen G. Clinical potential of electroporation for gene therapy and DNA vaccine delivery. Expert Opin Drug Deliv. 2016; 13:295-310. https://doi.org/10.1517/1742524 7.2016.1121990.

18. Spanggaard I, Snoj M, Cavalcanti A, Bouquet C, Sersa G, Robert C, Cemazar M, Dam E, Vasseur B, Attali P, Mir LM, Gehl J. Gene electrotransfer of plasmid antiangiogenic metargidin peptide (AMEP) in disseminated melanoma: safety and efficacy results of a phase I first-in-man study. Hum Gene Ther Clin Dev. 2013; 24:99-107. https://doi. org/10.1089/humc.2012.240.

19. Golzio M, Escoffre JM, Portet T, Mauroy C, Teissié J, Dean DS, Rols MP. Observations of the mechanisms of electromediated DNA uptake-from vesicles to tissues. Curr Gene Ther. 2010; 10:256-66. https://doi. org/10.2174/156652310791823461.

20. Escoffre JM, Portet T, Favard C, Teissié J, Dean DS, Rols MP. Electromediated formation of DNA complexes with cell membranes and its consequences for gene delivery. Biochim Biophys Acta. 2011; 1808:1538-43. https://doi. org/10.1016/j.bbamem.2010.10.009.

21. Rosazza C, Deschout H, Buntz A, Braeckmans K, Rols MP, Zumbusch A. Endocytosis and Endosomal Trafficking of DNA After Gene Electrotransfer In Vitro. Mol Ther Nucleic Acids. 2016; 5:e286. https://doi.org/10.1038/mtna.2015.59.

22. Mao M, Wang L, Chang CC, Rothenberg KE, Huang J, Wang Y, Hoffman BD, Liton PB, Yuan F. Involvement of a Rac1-Dependent Macropinocytosis Pathway in Plasmid DNA Delivery by Electrotransfection. Mol Ther. 2017; 25:803-15. https://doi.org/10.1016/j.ymthe.2016.12.009.

23. Markelc B, Skvarca E, Dolinsek T, Kloboves VP, Coer A, Sersa G, Cemazar M. Inhibitor of endocytosis impairs gene electrotransfer to mouse muscle in vivo. Bioelectrochemistry. 2015; 103:111-19. https://doi. org/10.1016/j.bioelechem.2014.08.020.

24. Wu M, Yuan F. Membrane binding of plasmid DNA and endocytic pathways are involved in electrotransfection of mammalian cells. PLoS One. 2011; 6:e20923. https://doi. org/10.1371/journal.pone.0020923.

25. Znidar K, Bosnjak M, Cemazar M, Heller LC. Cytosolic DNA Sensor Upregulation Accompanies DNA Electrotransfer in B16.F10 Melanoma Cells. Mol Ther Nucleic Acids. 2016; 5:e322. https://doi.org/10.1038/ mtna.2016.34.

26. Nguyen J, Szoka FC. Nucleic acid delivery: the missing pieces of the puzzle? Acc Chem Res. 2012; 45:1153-62. https://doi.org/10.1021/ar3000162.

27. Smith KC, Neu JC, Krassowska W. Model of creation and evolution of stable electropores for DNA delivery. 
Biophys J. 2004; 86:2813-26. https://doi.org/10.1016/ S0006-3495(04)74334-9.

28. Pavlin M, Kandušer M. New insights into the mechanisms of gene electrotransfer-experimental and theoretical analysis. Sci Rep. 2015; 5:9132. https://doi.org/10.1038/ srep09132.

29. Desmet CJ, Ishii KJ. Nucleic acid sensing at the interface between innate and adaptive immunity in vaccination. Nat Rev Immunol. 2012; 12:479-91. https://doi.org/10.1038/ nri3247.

30. Paludan SR, Bowie AG. Immune sensing of DNA. Immunity. 2013; 38:870-80. https://doi.org/10.1016/j. immuni.2013.05.004.

31. Broz P, Monack DM. Newly described pattern recognition receptors team up against intracellular pathogens. Nat Rev Immunol. 2013; 13:551-65. https://doi.org/10.1038/ nri3479.

32. Hornung V, Latz E. Intracellular DNA recognition. Nat Rev Immunol. 2010; 10:123-30. https://doi.org/10.1038/ nri2690.

33. Liu J, Cao X. Cellular and molecular regulation of innate inflammatory responses. Cell Mol Immunol. 2016; 13:71121. https://doi.org/10.1038/cmi.2016.58.

34. Heller LC, Coppola D. Electrically mediated delivery of vector plasmid DNA elicits an antitumor effect. Gene Ther. 2002; 9:1321-25. https://doi.org/10.1038/sj.gt.3301802.

35. Heller L, Todorovic V, Cemazar M. Electrotransfer of single-stranded or double-stranded DNA induces complete regression of palpable B16.F10 mouse melanomas. Cancer Gene Ther. 2013; 20:695-700. https://doi.org/10.1038/ cgt.2013.71.

36. Niu G, Heller R, Catlett-Falcone R, Coppola D, Jaroszeski M, Dalton W, Jove R, Yu H. Gene therapy with dominantnegative Stat 3 suppresses growth of the murine melanoma B16 tumor in vivo. Cancer Res. 1999; 59:5059-63.

37. Slack A, Bovenzi V, Bigey P, Ivanov MA, Ramchandani S, Bhattacharya S, tenOever B, Lamrihi B, Scherman D, Szyf M. Antisense MBD2 gene therapy inhibits tumorigenesis. J Gene Med. 2002; 4:381-89. https://doi.org/10.1002/ jgm.288.

38. Grosel A, Sersa G, Kranjc S, Cemazar M. Electrogene therapy with p53 of murine sarcomas alone or combined with electrochemotherapy using cisplatin. DNA Cell Biol. 2006; 25:674-83. https://doi.org/10.1089/dna.2006.25.674.

39. McCray AN, Ugen KE, Muthumani K, Kim JJ, Weiner DB, Heller R. Complete regression of established subcutaneous B16 murine melanoma tumors after delivery of an HIV-1 Vpr-expressing plasmid by in vivo electroporation. Mol Ther. 2006; 14:647-55. https://doi.org/10.1016/j. ymthe.2006.06.010.

40. Ugen KE, Kutzler MA, Marrero B, Westover J, Coppola D, Weiner DB, Heller R. Regression of subcutaneous B16 melanoma tumors after intratumoral delivery of an IL-15expressing plasmid followed by in vivo electroporation.
Cancer Gene Ther. 2006; 13:969-74. https://doi. org/10.1038/sj.cgt.7700973.

41. Wang Z, Choi MK, Ban T, Yanai H, Negishi $H$, Lu Y, Tamura T, Takaoka A, Nishikura K, Taniguchi T. Regulation of innate immune responses by DAI (DLM-1/ ZBP1) and other DNA-sensing molecules. Proc Natl Acad Sci USA. 2008; 105:5477-82. https://doi.org/10.1073/ pnas.0801295105.

42. Heller LC, Cruz YL, Ferraro B, Yang H, Heller R. Plasmid injection and application of electric pulses alter endogenous mRNA and protein expression in B16.F10 mouse melanomas. Cancer Gene Ther. 2010; 17:864-71. https:// doi.org/10.1038/cgt.2010.43.

43. Vidic S, Markelc B, Sersa G, Coer A, Kamensek U, Tevz G, Kranjc S, Cemazar M. MicroRNAs targeting mutant K-ras by electrotransfer inhibit human colorectal adenocarcinoma cell growth in vitro and in vivo. Cancer Gene Ther. 2010; 17:409-19. https://doi.org/10.1038/cgt.2009.87.

44. Marrero B, Shirley S, Heller R. Delivery of interleukin-15 to B16 melanoma by electroporation leads to tumor regression and long-term survival. Technol Cancer Res Treat. 2014; 13:551-60. https://doi.org/10.7785/ tcrtexpress.2013.600252.

45. Forde PF, Hall LJ, Sadadcharam M, de Kruijf M, O'Sullivan GC, Soden DM. Development and characterization of an enhanced nonviral expression vector for electroporation cancer treatment. Mol Ther Methods Clin Dev. 2014; 1:14012. https://doi.org/10.1038/mtm.2014.12.

46. Deigendesch N, Koch-Nolte F, Rothenburg S. ZBP1 subcellular localization and association with stress granules is controlled by its Z-DNA binding domains. Nucleic Acids Res. 2006; 34:5007-20. https://doi.org/10.1093/nar/gk1575.

47. Takaoka A, Wang Z, Choi MK, Yanai H, Negishi H, Ban T, Lu Y, Miyagishi M, Kodama T, Honda K, Ohba Y, Taniguchi T. DAI (DLM-1/ZBP1) is a cytosolic DNA sensor and an activator of innate immune response. Nature. 2007; 448:501-05. https://doi.org/10.1038/nature06013.

48. Trinchieri G. Type I interferon: friend or foe? J Exp Med. 2010; 207:2053-63. https://doi.org/10.1084/jem.20101664.

49. Bosnjak M, Jesenko T, Kamensek U, Sersa G, Lavrencak J, Heller LC, Cemazar M. Electrotransfer of different control plasmids elicits different antitumor effectiveness in B16. F10 melanoma. Cancers. 2018; 10:1-14.

50. Stimac M, Dolinsek T, Lampreht U, Cemazar M, Sersa G. Gene electrotransfer of plasmid with tissue specific promoter encoding shRNA against endoglin exerts antitumor efficacy against murine TS/A tumors by vascular targeted effects. PLoS One. 2015; 10:e0124913. https://doi. org/10.1371/journal.pone.0124913.

51. Prosen L, Markelc B, Dolinsek T, Music B, Cemazar M, Sersa G. Mcam Silencing With RNA Interference Using Magnetofection has Antitumor Effect in Murine Melanoma. Mol Ther Nucleic Acids. 2014; 3:e205. https:// doi.org/10.1038/mtna.2014.56. 
52. Bosnjak M, Dolinsek T, Cemazar M, Kranjc S, Blagus T, Markelc B, Stimac M, Zavrsnik J, Kamensek U, Heller L, Bouquet C, Turk B, Sersa G. Gene electrotransfer of plasmid AMEP, an integrin-targeted therapy, has antitumor and antiangiogenic action in murine B16 melanoma. Gene Ther. 2015; 22:578-90. https://doi.org/10.1038/gt.2015.26.

53. Cemazar M, Sersa G, Wilson J, Tozer GM, Hart SL, Grosel A, Dachs GU. Effective gene transfer to solid tumors using different nonviral gene delivery techniques: electroporation, liposomes, and integrin-targeted vector. Cancer Gene Ther. 2002; 9:399-406. https://doi.org/10.1038/sj.cgt.7700454.

54. Cemazar M, Pavlin D, Kranjc S, Grosel A, Mesojednik S, Sersa G. Sequence and time dependence of transfection efficiency of electrically-assisted gene delivery to tumors in mice. Curr Drug Deliv. 2006; 3:77-81. https://doi. org/10.2174/156720106775197556.

55. Cemazar M, Golzio M, Sersa G, Hojman P, Kranjc S, Mesojednik S, Rols MP, Teissie J. Control by pulse parameters of DNA electrotransfer into solid tumors in mice. Gene Ther. 2009; 16:635-44. https://doi.org/10.1038/ gt.2009.10.

56. Yarmush ML, Golberg A, Serša G, Kotnik T, Miklavčič D. Electroporation-based technologies for medicine: principles, applications, and challenges. Annu Rev Biomed Eng. 2014; 16:295-320. https://doi.org/10.1146/ annurev-bioeng-071813-104622.

57. Cemazar M, Golzio M, Sersa G, Escoffre JM, Coer A, Vidic S, Teissie J. Hyaluronidase and collagenase increase the transfection efficiency of gene electrotransfer in various murine tumors. Hum Gene Ther. 2012; 23:128-37. https:// doi.org/10.1089/hum.2011.073.

58. Bureau MF, Gehl J, Deleuze V, Mir LM, Scherman D. Importance of association between permeabilization and electrophoretic forces for intramuscular DNA electrotransfer. Biochim Biophys Acta. 2000; 1474:353-59. https://doi.org/10.1016/S0304-4165(00)00028-3.

59. Satkauskas S, André F, Bureau MF, Scherman D, Miklavcic D, Mir LM. Electrophoretic component of electric pulses determines the efficacy of in vivo DNA electrotransfer. Hum Gene Ther. 2005; 16:1194-201. https://doi.org/10.1089/ hum.2005.16.1194.

60. Kandušer M, Miklavčič D, Pavlin M. Mechanisms involved in gene electrotransfer using high- and low-voltage pulsesan in vitro study. Bioelectrochemistry. 2009; 74:265-71. https://doi.org/10.1016/j.bioelechem.2008.09.002.

61. Tevz G, Pavlin D, Kamensek U, Kranjc S, Mesojednik S, Coer A, Sersa G, Cemazar M. Gene electrotransfer into murine skeletal muscle: a systematic analysis of parameters for long-term gene expression. Technol Cancer Res Treat. 2008; 7:91-101. https://doi. org/10.1177/153303460800700201.

62. Beebe SJ, Fox PM, Rec LJ, Willis EL, Schoenbach KH. Nanosecond, high-intensity pulsed electric fields induce apoptosis in human cells. FASEB J. 2003; 17:1493-95. https://doi.org/10.1096/fj.02-0859fje.
63. Xiao S, Guo S, Nesin V, Heller R, Schoenbach KH. Subnanosecond electric pulses cause membrane permeabilization and cell death. IEEE Trans Biomed Eng. 2011; 58:1239-45. https://doi.org/10.1109/ TBME.2011.2112360.

64. Nuccitelli R, Pliquett U, Chen X, Ford W, James Swanson R, Beebe SJ, Kolb JF, Schoenbach KH. Nanosecond pulsed electric fields cause melanomas to self-destruct. Biochem Biophys Res Commun. 2006; 343:351-60. https://doi. org/10.1016/j.bbrc.2006.02.181.

65. Pakhomova ON, Gregory BW, Khorokhorina VA, Bowman AM, Xiao S, Pakhomov AG. Electroporation-induced electrosensitization. PLoS One. 2011; 6:e17100. https://doi. org/10.1371/journal.pone.0017100.

66. Meulenberg CJ, Todorovic V, Cemazar M. Differential cellular effects of electroporation and electrochemotherapy in monolayers of human microvascular endothelial cells. PLoS One. 2012; 7:e52713. https://doi.org/10.1371/journal. pone. 0052713 .

67. Ziegler MJ, Vernier PT. Interface water dynamics and porating electric fields for phospholipid bilayers. J Phys Chem B. 2008; 112:13588-96. https://doi.org/10.1021/ jp8027726.

68. Escoffre JM, Bellard E, Faurie C, Sébaï SC, Golzio M, Teissié J, Rols MP. Membrane disorder and phospholipid scrambling in electropermeabilized and viable cells. Biochim Biophys Acta. 2014; 1838:1701-9. https://doi. org/10.1016/j.bbamem.2014.02.013.

69. Rols MP, Teissie J. Ionic-strength modulation of electrically induced permeabilization and associated fusion of mammalian cells. Eur J Biochem. 1989; 179:109-15. https://doi.org/10.1111/j.1432-1033.1989.tb14527.x.

70. Li LH, Sen A, Murphy SP, Jahreis GP, Fuji H, Hui SW. Apoptosis induced by DNA uptake limits transfection efficiency. Exp Cell Res. 1999; 253:541-50. https://doi. org/10.1006/excr.1999.4666.

71. Lesueur LL, Mir LM, André FM. Overcoming the specific toxicity of large plasmids electrotransfer in primary cells in vitro. Mol Ther Nucleic Acids. 2016; 5:e291. https://doi. org/10.1038/mtna.2016.4.

72. Znidar $\mathrm{K}$, Bosnjak $\mathrm{M}$, Heller LC, Čemažar $\mathrm{M}$. Electrostransfer of plasmid gWIZ blank into B16F10 and TS/A increase expression of cytosolic DNA PRRs. IFMBE Proc. 2016; 53:183-86. https://doi. org/10.1007/978-981-287-817-5_41.

73. Riss TL, Moravec RA, Niles AL. Cytotoxicity testing: measuring viable cells, dead cells, and detecting mechanism of cell death. Methods Mol Biol. 2011; 740:103-14. https:// doi.org/10.1007/978-1-61779-108-6_12.

74. Zhu W, Liu P, Yu L, Chen Q, Liu Z, Yan K, Lee WM, Cheng CY, Han D. p204-initiated innate antiviral response in mouse Leydig cells. Biol Reprod. 2014; 91:8-8. https:// doi.org/10.1095/biolreprod.114.119396.

75. Landolfo S, Gariglio M, Gribaudo G, Lembo D. The Ifi 200 genes: an emerging family of IFN-inducible genes. 
Biochimie. 1998; 80:721-28. https://doi.org/10.1016/ S0300-9084(99)80025-X.

76. Yang P, An H, Liu X, Wen M, Zheng Y, Rui Y, Cao X. The cytosolic nucleic acid sensor LRRFIP1 mediates the production of type I interferon via a beta-catenin-dependent pathway. Nat Immunol. 2010; 11:487-94. https://doi. org/10.1038/ni.1876.

77. de Weerd NA, Nguyen T. The interferons and their receptors - distribution and regulation. Immunol Cell Biol. 2012; 90:483-91. https://doi.org/10.1038/icb.2012.9.

78. Vogel C, Marcotte EM. Insights into the regulation of protein abundance from proteomic and transcriptomic analyses. Nat Rev Genet. 2012; 13:227-32. https://doi. org/10.1038/nrg3185.

79. Miyashita M, Oshiumi H, Matsumoto M, Seya T. DDX60, a $\mathrm{DEXD} / \mathrm{H}$ box helicase, is a novel antiviral factor promoting RIG-I-like receptor-mediated signaling. Mol Cell Biol. 2011; 31:3802-19. https://doi.org/10.1128/MCB.01368-10.

80. Unterholzner L, Keating SE, Baran M, Horan KA, Jensen SB, Sharma S, Sirois CM, Jin T, Latz E, Xiao TS, Fitzgerald KA, Paludan SR, Bowie AG. IFI16 is an innate immune sensor for intracellular DNA. Nat Immunol. 2010; 11:9971004. https://doi.org/10.1038/ni.1932.

81. Søby S, Laursen RR, Østergaard L, Melchjorsen J. HSV1-induced chemokine expression via IFI16-dependent and IFI16-independent pathways in human monocytederived macrophages. Herpesviridae. 2012; 3:6. https://doi. org/10.1186/2042-4280-3-6.

82. Keating SE, Baran M, Bowie AG. Cytosolic DNA sensors regulating type I interferon induction. Trends Immunol. 2011; 32:574-81. https://doi.org/10.1016/j.it.2011.08.004.

83. Kuriakose T, Kanneganti TD. ZBP1: Innate sensor regulating cell death and inflammation. Trends Immunol. 2018; 39:123-34. https://doi.org/10.1016/j.it.2017.11.002.

84. Panichakul T, Wanun T, Reutrakul V, Sirisinha S. Synergistic cytotoxicity and apoptosis induced in human cholangiocarcinoma cell lines by a combined treatment with tumor necrosis factor-alpha (TNF-alpha) and triptolide. Asian Pac J Allergy Immunol. 2002; 20:167-73. http://search. proquest.com/docview/1030972731 ?accountid=27797.

85. Serša G, Čemažar M, Menart V, Gaberc-Porekar V, Miklavčič D. Anti-tumor effectiveness of electrochemotherapy with bleomycin is increased by TNF- $\alpha$ on SA-1 tumors in mice. Cancer Lett. 1997; 116:85-92. https://doi.org/10.1016/S0304-3835(97)00170-5.

86. Cemazar M, Todorovic V, Scancar J, Lampreht U, Stimac M, Kamensek U, Kranjc S, Coer A, Sersa G. Adjuvant TNF- $\alpha$ therapy to electrochemotherapy with intravenous cisplatin in murine sarcoma exerts synergistic antitumor effectiveness. Radiol Oncol. 2015; 49:32-40. https://doi. org/10.1515/raon-2015-0005.

87. Havunen R, Siurala M, Sorsa S, Grönberg-Vähä-Koskela S, Behr M, Tähtinen S, Santos JM, Karell P, Rusanen J, Nettelbeck DM, Ehrhardt A, Kanerva A, Hemminki A. Oncolytic Adenoviruses Armed with Tumor Necrosis Factor Alpha and Interleukin-2 Enable Successful Adoptive Cell
Therapy. Mol Ther Oncolytics. 2016; 4:77-86. https://doi. org/10.1016/j.omto.2016.12.004.

88. Sumi H, Inazuka M, Hashimoto K, Ishikawa T, Yoshida S, Yabuki M. T-3256336, a novel and orally available small molecule IAP antagonist, induced tumor cell death via induction of systemic TNF alpha production. Biochem Biophys Res Commun. 2016; 479:179-85. https://doi. org/10.1016/j.bbrc.2016.09.019.

89. Parker BS, Rautela J, Hertzog PJ. Antitumour actions of interferons: implications for cancer therapy. Nat Rev Cancer. 2016; 16:131-44. https://doi.org/10.1038/nrc.2016.14.

90. Naudé PJ, den Boer JA, Luiten PG, Eisel UL. Tumor necrosis factor receptor cross-talk. FEBS J. 2011; 278:88898. https://doi.org/10.1111/j.1742-4658.2011.08017.x.

91. Pasparakis M, Vandenabeele P. Necroptosis and its role in inflammation. Nature. 2015; 517:311-20. https://doi. org/10.1038/nature14191.

92. Linkermann A, Green DR. Necroptosis. N Engl J Med. 2014; 370:455-65. https://doi.org/10.1056/ NEJMra1310050.

93. Nanni P, de Giovanni C, Lollini PL, Nicoletti G, Prodi G. TS/A: a new metastasizing cell line from a BALB/c spontaneous mammary adenocarcinoma. Clin Exp Metastasis. 1983; 1:373-80. https://doi.org/10.1007/BF00121199.

94. Bosnjak M, Lorente BC, Pogacar Z, Makovsek V, Cemazar M. Different incubation times of cells after gene electrotransfer in fetal bovine serum affect cell viability, but not transfection efficiency. J Membr Biol. 2014; 247:42128. https://doi.org/10.1007/s00232-014-9649-9.

95. Bosnjak M, Prosen L, Dolinsek T, Blagus T, Markelc B, Cemazar M, Bouquet C, Sersa G. Biological properties of melanoma and endothelial cells after plasmid AMEP gene electrotransfer depend on integrin quantity on cells. J Membr Biol. 2013; 246:803-19. https://doi.org/10.1007/ s00232-013-9550-y.

96. Čemažar M, Marolt D, Lavrič M, Serša G. Comparison of colorimetric MTT and clonogenic assays for irradiation and cisplatin treatment on murine fibrosarcoma SA-1 cells. Radiol Oncol. 1999; 4:303-08.

97. Schneider CA, Rasband WS, Eliceiri KW. NIH Image to ImageJ: 25 years of image analysis. Nat Methods. 2012; 9:671-75. https://doi.org/10.1038/nmeth.2089.

98. Stetson DB, Medzhitov R. Recognition of cytosolic DNA activates an IRF3-dependent innate immune response. Immunity. 2006; 24:93-103. https://doi.org/10.1016/j. immuni.2005.12.003.

99. DeFilippis VR, Alvarado D, Sali T, Rothenburg S, Früh K. Human cytomegalovirus induces the interferon response via the DNA sensor ZBP1. J Virol. 2010; 84:585-98. https:// doi.org/10.1128/JVI.01748-09.

100. Upton JW, Kaiser WJ, Mocarski ES. DAI/ZBP1/DLM-1 complexes with RIP3 to mediate virus-induced programmed necrosis that is targeted by murine cytomegalovirus vIRA. Cell Host Microbe. 2012; 11:290-97. https://doi. org/10.1016/j.chom.2012.01.016. 